\title{
White Rock Oneota Chipped Stone Tools
}

\author{
Matthew J. Padilla and Lauren W. Ritterbush
}

Matthew J. Padilla, Department of Sociology and Anthropology, New Mexico State University, Las Cruces, NM 88003-8001 (mjp9999@nmsu.edu). Lauren W. Ritterbush, Department of Sociology, Anthropology, and Social Work, Kansas State University, 204 Waters Hall, Manhattan, KS 66506 (Iritterb@ksu.edu).

ABSTRACT

\begin{abstract}
A standardized approach to descriptive analysis of chipped stone artifacts from the White Rock site (14JW1) in north-central Kansas allows comparison with Oneota lithic assemblages. These comparisons reinforce the interpretation of the White Rock phase as the remains of a late prehistoric Oneota population in the Central Plains. White Rock peoples made tool forms (e.g., small triangular points) similar to those recovered from Oneota sites in the Midwest. Informal tools are well represented, reflecting an Oneota lithic technology. Despite continuity in chipped stone tool production, regional adaptation is evident in the selection of lithic raw materials from the Central Plains, production of blades and blade tools, and an abundance of scrapers. The latter, along with beveled knives, reveals extensive processing of bison hides and meat, a reflection of Oneota adaptation to the Plains.
\end{abstract}

The goal of this study is to provide a formal description and comparative analysis of chipped stone objects in a sample assemblage from the White Rock site (14JW1) in north-central Kansas. This is the type site of the White Rock phase, which represents the remains of late prehistoric Oneota migrants in the Central Plains (Logan 1995, 1998b; Ritterbush 2002a; Ritterbush and Logan 2000). Given the analytical emphasis on ceramics in Oneota assemblages, this interpretation has largely been based on similarities in ceramic attributes. Use of a standardized descriptive classification for chipped stone objects allows testing of this interpretation using nonceramic artifacts. Similarities in chipped stone tools should exist between Midwestern Oneota and White Rock assemblages. However, differences in environment, subsistence and other activities also may have produced variations in White Rock lithic subassemblages. Through this study we hope to add to the literature on Oneota lithic artifacts, further the use of standardized descrip- 
tive classification, test the Oneota affiliation of the White Rock phase, and discuss differences in the lithic subassemblage that may reflect the distinctive White Rock Oneota adaptation to the western Plains.

\section{Background}

The White Rock site is an extensive late prehistoric archaeological site located in Jewell County, north-central Kansas (Figure 1) (Rusco 1960:48). Today this site lies near the north bank of Lovewell Reservoir on property managed by the Bureau of Reclamation (BOR). Similar sites are situated on nearby landforms, marking this locality as an attractive place of settlement during late prehistory. This was noted by early Plains archaeologists who visited this and nearby sites as early as the 1930s (Cooper 1937; Lamb 1935). Nonetheless, few analytical studies (Marshall 1969; Rusco 1960) focused on materials from this and other White Rock sites until relatively recently. Within the last two decades, renewed interest in these remains has led to further analyses and recognition of the significance of these remains in interpreting the past cultural dynamics of the Plains (e.g., Blakeslee et al. 2001; Logan 1995, 1998b; Ritterbush 2002a, 2003; Ritterbush and Logan 2000).

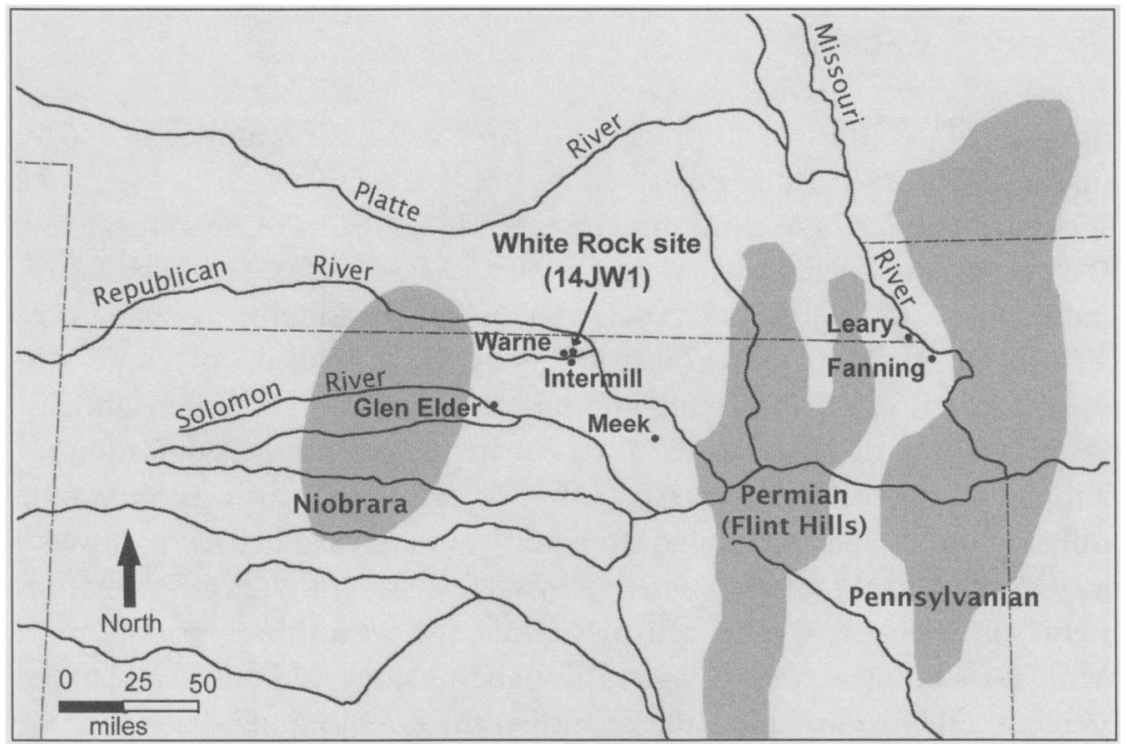

Figure 1 Map of the Central Plains illustrating the location of White Rock phase sites in Kansas and source areas for chert. 
George Lamb conducted the first documented survey of the White Rock site in 1935 for the Nebraska State Historical Society (NSHS). A.T. Hill, avocational archaeologist and later director of the NSHS museum, appears to have visited this site prior to 1935 and sent Lamb to investigate it further. During his inspection, Lamb excavated a cache pit and hearth (Lamb 1935). Two years later, Lamb and Paul Cooper returned and observed potsherds, flint chips, end scrapers, fragments of burned limestone, and other artifacts (Cooper 1937). Focusing on the area Lamb investigated two years earlier, they conducted more extensive excavations and uncovered two possible house floors and several cache pits (Cooper 1937; Rusco 1960:48-54). Little was reported about these early investigations, and the 1935 and 1937 surface and excavated collections, as well as another collection (presumably A.T. Hill's personal collection from the site) remained at the NSHS until 1989, when they were transferred to the Kansas State Historical Society (KSHS). Mary Kiehl Rusco analyzed a portion of the 1930s assemblage as part of her Masters thesis in 1960. Her analysis did not include the entire assemblage since projectile points were the only chipped stone tools available at that time (Rusco 1960:59-60).

Other investigations have been undertaken at the White Rock site since the 1930s. In 1951, Franklin Fenenga visited the site during a River Basin Survey prior to the construction of Lovewell Reservoir (Cooper 1955:13-14; Fenenga and Cooper 1951). Robert W. Newman (1956, 1963) conducted test excavations at the White Rock site, in addition to the related Warne and Intermill sites, for the Smithsonian Institution in 1956. More recently, Brad Logan with the University of Kansas Museum of Anthropology (KUMA) completed surveys and test excavations at the White Rock and other sites on the BOR property surrounding Lovewell Reservoir (Logan 1993, 1995; Logan and Banks 1994; Logan and Hedden 1992). These studies provide valuable data for interpreting this and related sites in the White Rock (Lovewell) locality. Growing interest in late prehistoric cultural changes in the Central Plains, combined with the most recent cultural resource management investigations at Lovewell Reservoir have brought renewed interest in the White Rock and comparable sites in the Central Plains.

Rusco's (1960:75) original analysis of several White Rock assemblages, including that from the White Rock site, resulted in the interpretation of this site as a "semi-permanent village" occupied by people who practiced both horticulture and hunting, particularly bison hunting. This range of subsistence practices was suited to the grassland environment of the Central Plains and specifically to the White Rock locality. The White Rock site lies on a low upland on the north side of White Rock Creek, a perennial stream 
now dammed to form Lovewell Reservoir. This and another major White Rock Oneota site, the Warne site, are extensive sites located on surfaces with thick Pleistocene loess deposits overlooking White Rock Creek valley (Fishel and Leonard 1955:19-20). To the north the rolling upland loess surface extends approximately five miles to the Republican River valley. This portion of the Central Plains is characterized as mixed-grass plains near the transition to short grasses to the west.

The White Rock site is the type-site of the White Rock phase. This phase is the westernmost representation of the Oneota tradition and has been dated to the latter portion of the Late Prehistoric period (Logan 1995, 1998b; Ritterbush and Logan 2000). Other White Rock phase sites have been recorded not only in this locality but also in southern Nebraska and other portions of north-central Kansas (Blakeslee et al. 2001; Logan 1993, 1995, 1998b; Logan and Banks 1994; Logan and Hedden 1992; Marshall 1969; Newman 1963; Ritterbush 1998, 2002b; Ritterbush and Logan 1991:8794, 2000; Rusco 1960;). These sites clearly indicate Oneota presence in the Central Plains and that Oneota occupation of the White Rock site was not an isolated occurrence. In addition, recent discoveries in southern Kansas reveal Oneota ceramics in assemblages assigned to the Plains Border variant (Bevitt 1999; Bevitt and Garst 2003). The latter artifacts are believed to indicate exchange between (or cohabitation by) populations of the High Plains with White Rock or more eastern Oneota peoples during the Late Prehistoric period (Ritterbush 2002c, 2003).

The distribution of White Rock phase sites in the heart of the Central Plains places them in proximity to other late prehistoric sites occupied by indigenous Plains populations. The latter, referred to by archaeologists as the Central Plains tradition, may have shifted their settlements away from this area as Oneota peoples entered the region as migrants from the east between about A. D. 1250-1300 (Logan 1995, 1998b; Ritterbush 2002a; Ritterbush and Logan 2000). No mixed assemblages of diagnostic White Rock Oneota and Central Plains tradition materials have been documented in this region, suggesting no or limited interaction between these populations. Differences between assemblages of these two traditions are most evident in the ceramics. The Oneota affiliation of the White Rock phase is most evident in the ceramics, which share distinctive attributes with Oneota potsherds recovered from Midwestern sites. The most characteristic of these are smooth surface treatment, rim form, and decoration. Like other late prehistoric Oneota ceramics, White Rock pottery is commonly decorated on the shoulder with parallel trailed lines that form nested chevrons, bordered 
by sets of vertical or oblique trailed lines, and embellished with punctates and other designs. White Rock ceramics clearly differ from typical Central Plains tradition vessels that have cord-roughened exteriors and rim, rather than shoulder, decorations. Despite the clear Oneota form of White Rock ceramics, they are distinctive in that they are occasionally simple-stamped and have much variability in temper. Unlike most Midwestern Oneota ceramics, which are shell-tempered, White Rock pottery is tempered with varied materials, especially sand, with limited amounts of shell (often very finely crushed) (Logan 1995; Marshall 1969; Ritterbush 2001; Rusco 1960). Other artifacts from White Rock phase sites are generally similar to those from late prehistoric and protohistoric Plains assemblages, although minor variations appear to exist (e.g., Owada and Ritterbush 1999). It is expected, based on the close correspondence of White Rock ceramic form and styles with those from Oneota sites to the east, that other similarities should exist. One goal of this analysis is to describe a sample of chipped stone artifacts from the White Rock site and compare these to other Oneota assemblages as a test of the Oneota affiliation of the White Rock site.

Traditionally, Oneota research has focused on ceramics. Because of this, Oneota lithic artifacts have received little attention. Descriptions of Midwestern Oneota assemblages suggest that Oneota chipped stone tools are commonly informal or "expediently manufactured" (Finney and Crawford 1999:51; Goatley 1995:162; Jeske 1992). Informal tools exhibit "little or no effort expended in their production" (Andrefsky 1994:22) and can include arrow points, scrapers, knives, and other tools commonly formed from flakes or blades with minimal preparation or retouch. In order to determine whether the White Rock people also relied on informal tools, a sample of chipped stone artifacts from the White Rock site was analyzed following a descriptive classificatory scheme developed for Midwestern assemblages (Lurie and Jeske 1990). This model of data recording has been applied with minor modifications to late prehistoric Oneota assemblages recovered from the La Crosse locality in Wisconsin (Goatley 1995; Hollinger 1993). A slightly modified version of this general classification scheme is also employed for this study. Given the general contemporaneity and ceramic similarities between the La Crosse Oneota and White Rock sites, these assemblages provide a good comparative base. Information regarding other Oneota assemblages in the Midwest and Plains, especially from the Glen Elder site, another late prehistoric White Rock site in the Central Plains, is used when comparable data can be extracted from their published descriptions. 


\section{Methods}

Data were collected for seven attributes for each chipped stone artifact: raw material, blank type, form, edge modification, completeness, weight, and artifact type. We added blank type to the existing classification system used by Lurie and Jeske (1990), Hollinger (1993), and Goatley (1995) in order to collect preliminary information on technology. Additional attributes (e.g., length and placement of working edge) were also recorded for specific tool classes (e.g., scrapers). All observations were made without magnification. This study did not involve formal use wear analysis, although macroscopic evidence of edge damage was noted for certain tools (e.g., scrapers).

\section{Raw Material}

Lithic raw material identifications were based on macroscopic observations and comparisons with samples in the lithic comparative collection of the Archaeology Lab at Kansas State University and published descriptions of lithic materials from the Central Plains and Midwest (Auckly et al. 2000; Blasing 1984; Carlson and Peacock 1975; Haury 1984; McLean 1998; Morrow 1994; Wright 1985).

\section{Blank Type}

We added the attribute of blank type to our data-recording scheme as a means of addressing whether specific forms of raw material were preferred by White Rock knappers. Identification of blank type was not based on a detailed technological analysis of the materials but did distinguish five general blank types: flake, blade, biface, cobble, and tabular piece. We hoped information collected for this attribute would provide basic descriptive information, as well as clues to whether more detailed technological analyses may be useful. Blank types were defined as follows:

A flake is a piece that was intentionally removed through percussion from a core. Artifacts that exhibit flake attributes, such as remnants of a ventral and dorsal surface, were classified as being made on flakes. The term blade was used to describe any elongated flake that has two long parallel lateral cutting edges (this can include flake blades, lamellar flakes, and true blades). As a general rule, a blade is at least twice as long as it is wide. This criterion may not define all blades since some artifacts, such as scrapers, were modified or repeatedly sharpened along the distal end reducing the overall length of the original piece. In this case, parallel flake scars on the 
dorsal surface, in addition to parallel lateral edges were used to identify blade blanks. A bifacial blank is a piece that exhibits flake scars on both surfaces to the extent that it is not possible to tell whether the original piece was a flake, blade, or tabular piece. The term 'tabular piece' is a new class added to our scheme and may not be useful in all chipped stone analyses. A tabular piece is a naturally occurring slab of lithic material that exhibits two generally parallel surfaces formed by natural bedding planes, cortex, or natural cortex-like material. This blank type may be unique to lithic subassemblages that include tools made on materials that naturally form in thin lenses or have parallel bedding planes, such as is common for Niobrara (Smoky Hill) jasper (Stein 2004). The thinness of these pieces often precludes flaking beyond marginal retouch.

\section{Form}

All artifacts were assigned to a class defined on the basis of general form of blank preparation. This classification reflects overall tool form and does not reflect how the working edge was formed. (Lurie and Jeske [1990] developed this classification, which has been slightly modified by Hollinger [1993] and Goatley [1995].) Five basic forms and one indeterminate category have been defined: edge-modified piece, bifacial, unifacial, multifacial, and nonfacial.

An edge-modified piece is commonly a marginally retouched or utilized piece of debitage characterized by minimal shaping, retouch or other modification. These pieces exhibit a single dorsal or ventral surface. This correlates with "Edge or Functional Unit Only" as listed by Lurie and Jeske (1990) but also includes blades that show human modification beyond removal from the objective piece. A bifacial piece is defined as an artifact with evidence that both faces of the piece have been shaped. These have at least one flake scar on each surface that cannot be traced to the edge of the piece. This type of flaking often produces artifacts with lenticular cross sections. An artifact that is classified as a unifacial piece was shaped beyond the edge on only one face. This is identified by the presence on only one surface of at least one flake scar that does not originate from the edge of the shaped piece. Multifacial artifacts exhibit intentional flake scars on more than two surfaces. These pieces often have a blocky appearance and may include cores. Nonfacial artifacts are rounded pieces with no well-defined faces or edges. They are usually produced by battering and are often formed through use rather than intentional modification. If the form of an artifact is unknown it is classified as indeterminate, meaning that it is a fragment 
that has been flaked or battered on a face or edge, but is too incomplete to assign to any of the above categories

\section{Edge Modification}

Classification of edge modification is based on Lurie and Jeske (1990:285286) and interprets how the edge (rather than the general form) of the artifact was modified (if at all) through intentional retouch or damage caused by use. Retouch is defined as at least three contiguous flake scars extending along at least $0.5 \mathrm{~cm}$ of the tool's edge and at least $1.0 \mathrm{~mm}$ onto the body of the piece (Lurie and Jeske 1990:285-286). Use wear is identified macroscopically and arbitrarily defined as microflaking, battering, grinding, polishing, or rounding that extends less than $0.5 \mathrm{~cm}$ along one or more edges and no more than $1.0 \mathrm{~mm}$ onto the body of the piece.

The edge of a utilized or retouched artifact may exhibit unifacial, bifacial, or unifacial and bifacial modification. An artifact that exhibits unifacial modification has one or more edges or edge segments that exhibits retouch or use wear extending onto a single face of the tool. A bifacial edge exhibits modification on both faces. If there is a combination of edge modifications, the artifact is described as having unifacial and bifacial retouch.

\section{Completeness}

Completeness describes whether an artifact is complete, nearly complete, or incomplete and which portion is present. Incomplete specimens may consist of the midsection, a lateral edge, proximal or distal end, indeterminate end, or indeterminate fragment. Nearly complete scrapers are divided into more specific categories that include which side is missing. This is important when analyzing working-edge placement (discussed below).

\section{Measurements}

Every artifact was weighed to the nearest tenth of a gram. The dimensions of complete artifacts (e.g., "knife" thickness, scraper length) were measured to the nearest tenth of a millimeter.

\section{Artifact Type}

The broadest category in which an artifact is described is artifact type. These formal-functional classes provide a means of describing and comparing 
lithic assemblages at a general level, yet also allow more specific formal, technological, and functional analysis of specific artifact types. Lurie and Jeske (1990) do not include this category in their classification scheme. However, Lurie (1990:218-219) refers to similar "paradigmatic classes" that can be derived from their classifications. We adopted most of Goatley's (1995:306) terminology for tool type categories, although, since Goatley did not provide definitions for these terms, our use of these terms may vary. Debitage was added as a class to separate unmodified from modified pieces. Utilized and retouched pieces were distinguished from one another using the above-mentioned guidelines for separating pieces showing evidence of probable use versus purposeful retouch. Goatley's retouched pebble category was omitted since no pebbles or pebble tools were present in this assemblage (no doubt a reflection of different raw materials in north-central Kansas versus southwestern Wisconsin). Each artifact type will be defined below as the White Rock data are presented.

\section{The Study Sample}

A total of 963 artifacts are included in the chipped stone subassemblage analyzed for this study. This includes those artifacts collected from the surface or through excavations at the White Rock site by personnel of the NSHS in the 1930s and additional lithic artifacts that appear to have been from A.T. Hill's collection from the site. As described above, these early field investigations were of limited extent, but included excavation of two possible houses and several pit features. Analysis of this sample allows preliminary description of White Rock chipped stone artifacts and comparisons with other Oneota remains.

Two raw material types predominat; Niobrara jasper (also known as Smoky Hill silicified chalk, Smoky Hill jasper, Republican River jasper, Graham County jasper, and Niobrarite) and Permian-age Flint Hills cherts (including Florence and Wreford [Three Mile and Shroyer] cherts). Niobrara jasper is found in parts of northwestern Kansas and extreme south-central Nebraska (Figure 1) (Stein 2004; Wright 1985). It is easily identified by its color and texture (Carlson and Peacock 1975; Stein 2004; Wright 1985). It is a relatively high-quality, homogenous chert that is commonly yellowish brown to brown; occasionally white, green or black; and yellowish red to dark reddish brown when heated. Niobrara jasper often forms in lenticular slabs with tan or white "cortex." This latter material is found on the exterior surface and as generally horizontal planes within the chert (making it difficult to distinguish between primary, secondary, and tertiary flaking debris). 
As a silicified chalk, minute white specks are commonly visible in the matrix. Although quality Niobrara jasper has a smooth texture, it is sometimes somewhat grainy. Occasionally, thin translucent to opaque white bands are present in the jasper. Several chipped stone artifacts from the White Rock site were made from a high-quality material believed, due to its brown to yellowish brown color, to be Niobrara jasper, but which is composed of semi-translucent (chalcedony-like) bands of clear to brown material.

Flint Hills cherts include a variety of gray to bluish-gray cherts that occur in different Permian-age limestone members and formations that outcrop in the Flint Hills physiographic province, which extends from near the Kansas-Nebraska border, through eastern Kansas, and into northern Oklahoma (Figure 1) (Auckly et al. 2000; Blasing 1984; Haury 1984). Color, inclusions, quality, and form are highly variable and are rarely diagnostic of the different Flint Hills cherts. In general, colors range from light to dark gray, with shades of bluish or brownish gray, occasionally white, and yellowish or greenish gray. Flint Hills cherts also display a very broad range of color patterns, from uniform to finely or broadly speckled, mottled, or banded. Fossil inclusions include fusilinids, echinoid spines, crinoids, bryozoa, and brachiopod fragments (Auckly et al. 2000). High-quality homogenous and almost translucent materials can be found among these cherts, but poor quality, soft and almost chalky samples can also be found. Chert within the Florence, Shroyer, and Three Mile members often occurs as beds of various thicknesses, but also occurs in rounded or oddly shaped nodules.

Nearly 70 percent of the chipped stone artifacts from the White Rock site are made from Niobrara jasper, while Flint Hills cherts make up approximately 21 percent of the subassemblage (Ritterbush and Logan 2000:265-266). A small number of artifacts appear to be made from Nehawka, Winterset or Stoner, and Burlington or other white unidentified cherts. The source areas for Nehawka, Winterset and Stoner cherts lie in southeastern Nebraska, northeastern Kansas, northwestern Missouri, and southwestern Iowa (Carlson and Peacock 1975; McLean 1998). Burlington chert is available in southeastern Iowa, northeastern and central Missouri, and west-central Illinois (McLean 1998; Morrow 1994). These are close to areas utilized by various Midwestern Oneota populations.

\section{Analysis}

Following is a discussion of the various chipped stone artifacts represented in the White Rock site assemblage. These include tools, blanks, and preforms, as well as waste debris. Although cores and debitage may have served 
as blanks for future tools, they are considered here to be waste debris, unless exhibiting evidence of use or retouch.

\section{Cores}

Cores are objective pieces from which flakes or blades were removed (Andrefsky 1998:9-11, 80). They are distinguished from debitage by the presence of flake removal scars, lack of a ventral surface, and, to separate them from shatter, a recognizable point(s) of applied force. Six cores (including one utilized core, mentioned again below as a utilized piece) were recovered from the White Rock site and make up less than one percent of the chipped stone subassemblage (Table 1). They range in weight from 27.6 to $119.9 \mathrm{~g}$, with the smallest being incomplete (shattered by heat). Four of the cores, including the utilized core, are Niobrara jasper. One is of Flint Hills (probably Three Mile) chert. The remaining core is so heavily burned that the material is unrecognizable. All have an unpatterned multifacial form.

\section{Debitage}

Debitage is simply any piece that has been detached from a core and exhibits no further evidence of human modification. There are 213 pieces of debitage (or 22.1 percent of the chipped stone artifacts) in this subassemblage (Table 1). Most of the debitage consists of relatively small flakes with an average weight of $4.1 \mathrm{~g}$. One relatively large tabular piece of debitage

Table 1. Artifact and tool type frequency.

\begin{tabular}{lrrr}
\hline Artifact Type & $\#$ & \% & Tool Type* \% \\
\hline Cores & 5 & .5 & - \\
Debitage & 213 & 22.1 & - \\
Bifaces & 221 & 22.9 & 29.7 \\
Unifaces & 16 & 1.7 & 2.1 \\
Scrapers & 248 & 25.8 & 33.3 \\
Triangular Points & 29 & 3.0 & 3.9 \\
Notched and Stemmed Points & 4 & .4 & .5 \\
Spokeshaves & 9 & .9 & 1.2 \\
Retouched Pieces & 165 & 17.1 & 22.1 \\
Utilized Pieces & 52 & 5.4 & 7.0 \\
Utilized Core & 1 & .1 & .1 \\
\hline
\end{tabular}

*Tool type excludes cores and debitage $(n=745)$. 
Table 2. Blank types for each artifact class.

\begin{tabular}{llrc}
\hline Artifact Type & Blank Type & $\#$ & $\%$ \\
\hline Cores & N/A & & \\
Debitage & Blade & 40 & 18.8 \\
& Flake & 171 & 80.3 \\
& Tabular & 1 & .5 \\
Bifaces & Shattered Core & 1 & .5 \\
& Bifacial & 184 & 83.3 \\
Unifaces & Blade & 1 & .5 \\
Scrapers & Tabular & 36 & 16.3 \\
Triangular Points & Blade & 12 & 75 \\
& Flake & 4 & 25 \\
Notched and Stemmed Points & Blade & 197 & 79.4 \\
Spokeshaves & Flake & 51 & 20.6 \\
& Bifacial & 19 & 65.5 \\
& Blade & 1 & 3.5 \\
Retouched Pieces & Flake & 9 & 31.0 \\
& Bifacial & 3 & 75 \\
& Flake & 1 & 25 \\
& Blade & 6 & 66.7 \\
& Flake & 1 & 11.1 \\
Utilized Pieces & Tabular & 2 & 22.2 \\
& Blade & 65 & 39.4 \\
& Flake & 90 & 54.6 \\
& Tabular & 8 & 4.9 \\
& Cobble & 1 & .6 \\
& Indeterminate & 1 & .6 \\
& Blade & 27 & 51.9 \\
& Flake & 25 & 48.1 \\
\hline
\end{tabular}

and a couple of large flakes and blades are also present. Approximately 80 percent of the debitage consists of flakes, while nearly 19 percent are blades (Table 2).

The following discussion focuses on those artifact types interpreted as functional tools or prepared specifically as blanks or preforms.

\section{Bifaces}

Two hundred twenty-one bifaces were recovered from the White Rock site (Table 1). These make up 23 percent of the chipped stone artifacts and nearly 30 percent of the tools in the study assemblage. Eighty-three bifaces are 


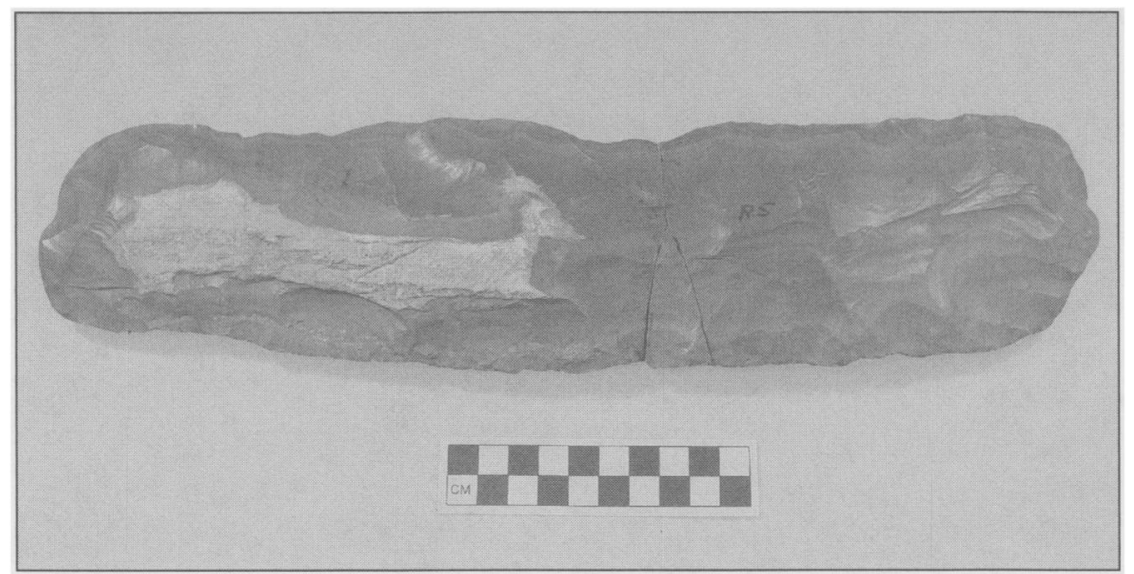

Figure 2 Largest biface in the White Rock site assemblage. Niobrara jasper.

complete, with the remaining 138 incomplete. There is much variability in the size of the complete bifaces, with weights ranging from 12.2-1126.0 g. The largest biface is long and narrow ( $365 \mathrm{~mm}$ long, $90 \mathrm{~mm}$ wide, $28.5 \mathrm{~mm}$ thick) (Figure 2). The eight next largest complete bifaces weigh between 506 and $658 \mathrm{~g}$. Two of these measure 217-240 $\mathrm{mm}$ long, 94-97 mm wide, and 21-23 mm thick (Figures $3 \& 4$ ). One of the large bifaces is broadly ovate, measuring $180 \mathrm{~mm}$ long, $130 \mathrm{~mm}$ wide, and $21 \mathrm{~mm}$ thick (Figure 5). Many of the others are also ovoid, although there is variability in form.

Nearly 81 percent of the bifaces are made from Niobrara jasper, including many of the largest bifaces. Of these, more than 16 percent are formed on tabular pieces. In several instances, striations in the cortex of some of the larger bifaces made from tabular pieces suggest that an attempt was made to remove this chalky material or to use this often flat surface, perhaps as a cutting surface or as a fine-grained abrader (Figure 5). This pattern of scraped or striated cortex has been observed on other Niobrara bifaces, including some from the Glen Elder site (Donald J. Blakeslee, personal communication, 2004). One biface appears to have been formed through bifacial flaking of a blade of Niobrara jasper (Table 2). Ten percent of the bifaces are made from Flint Hills cherts. The remainder is of quartzite, Nehawka chert, and other unidentified materials.

It is difficult to identify the function of the bifaces at the White Rock site without formal use-wear analysis. More than one-third of the bifaces exhibit edge retouch, suggesting purposeful shaping for use as a finished tool. Many of these are relatively thin, ranging in thickness from $4.2-14.2 \mathrm{~mm}$ (mean $=8.5 \mathrm{~mm}$ ), and have generally straight working edges along one or 


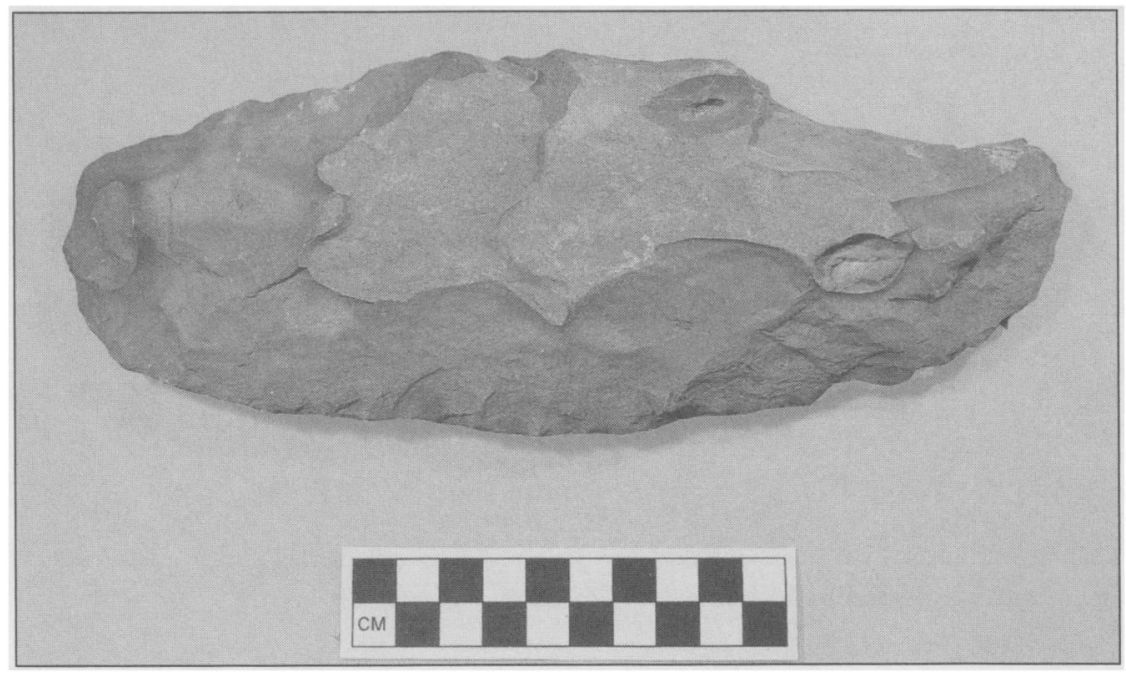

Figure 3 Large biface of Niobrara jasper.

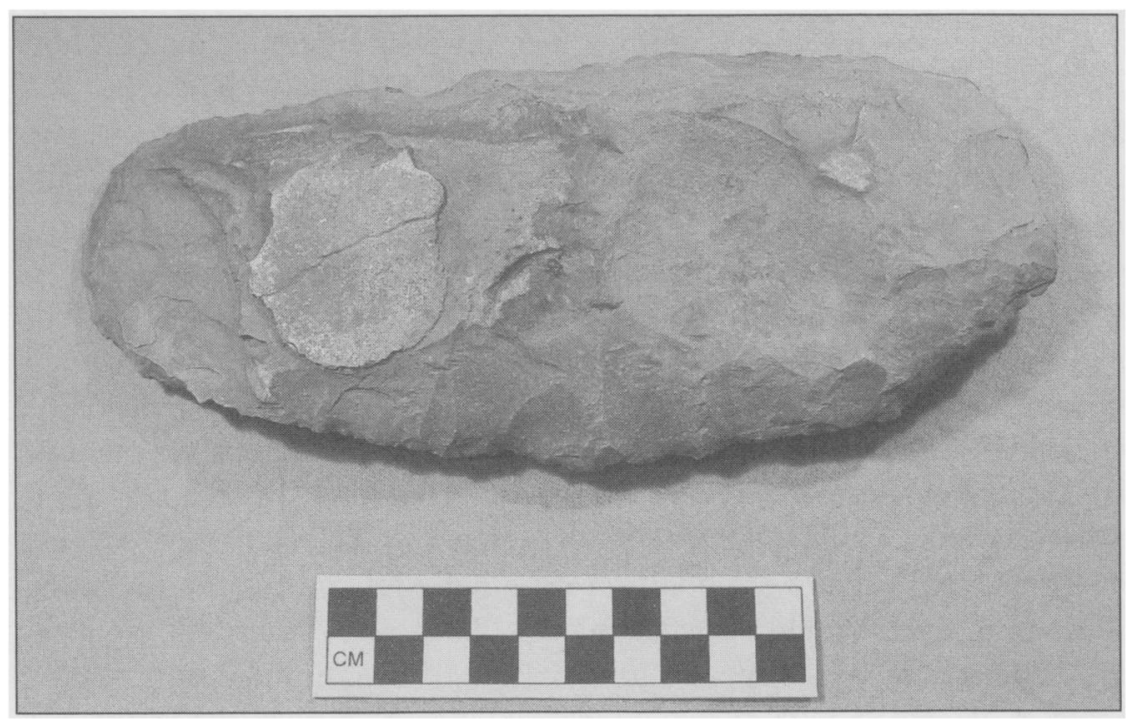

Figure 4 Large biface of Niobrara jasper.

more lateral edges. These edges would be well suited for cutting, suggesting that the thinner bifaces with finished working edges may have functioned as knives (Figure 6). Approximately three-quarters of the "knives" have one or more beveled edges, likely formed through resharpening. A technological study by Sollberger (1971) of beveled knives commonly found in the central and southern Plains indicated that their form resulted from the pur- 


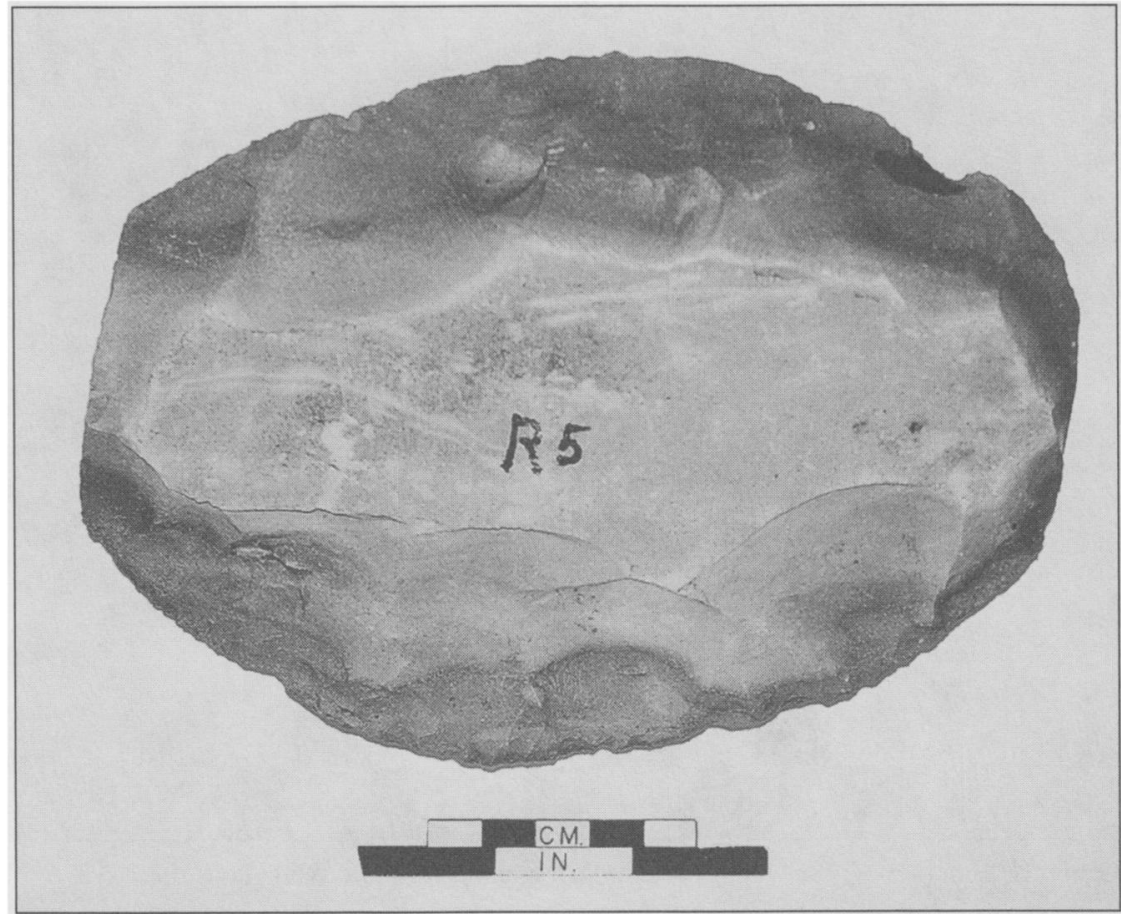

Figure 5 Large ovate biface with fine striations in cortex remaining on this tabular piece of Niobrara jasper.

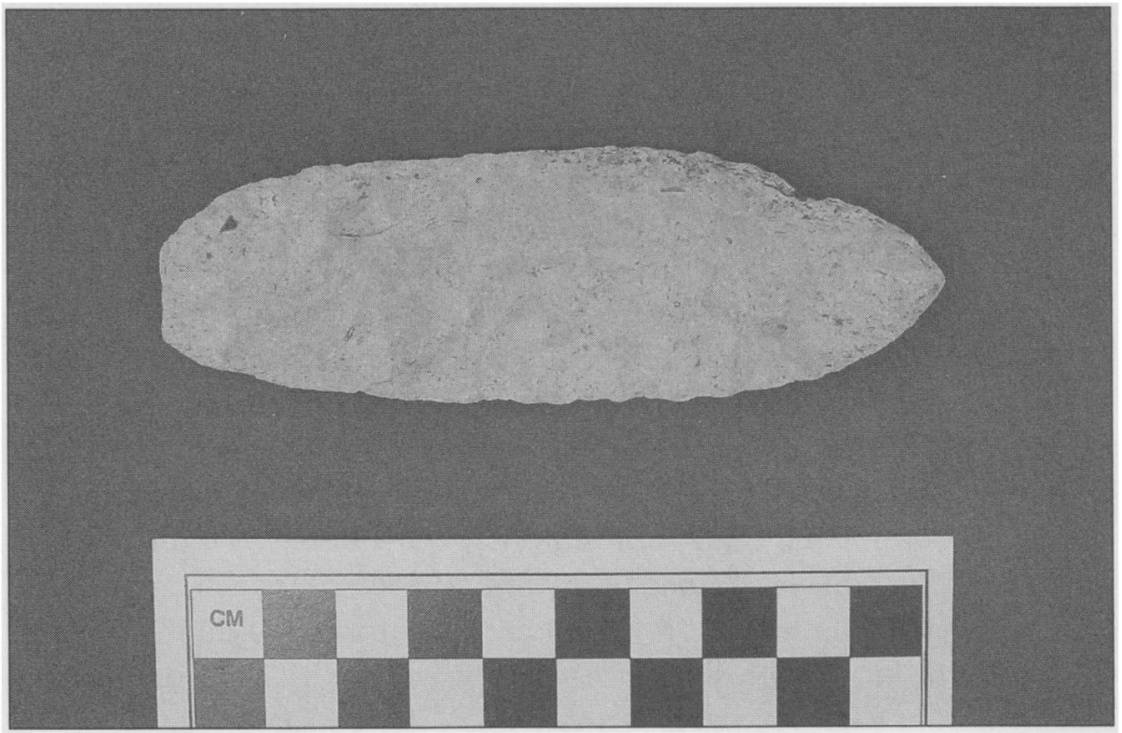

Figure 6 Thin bifacial "knife" of unidentified chert. 


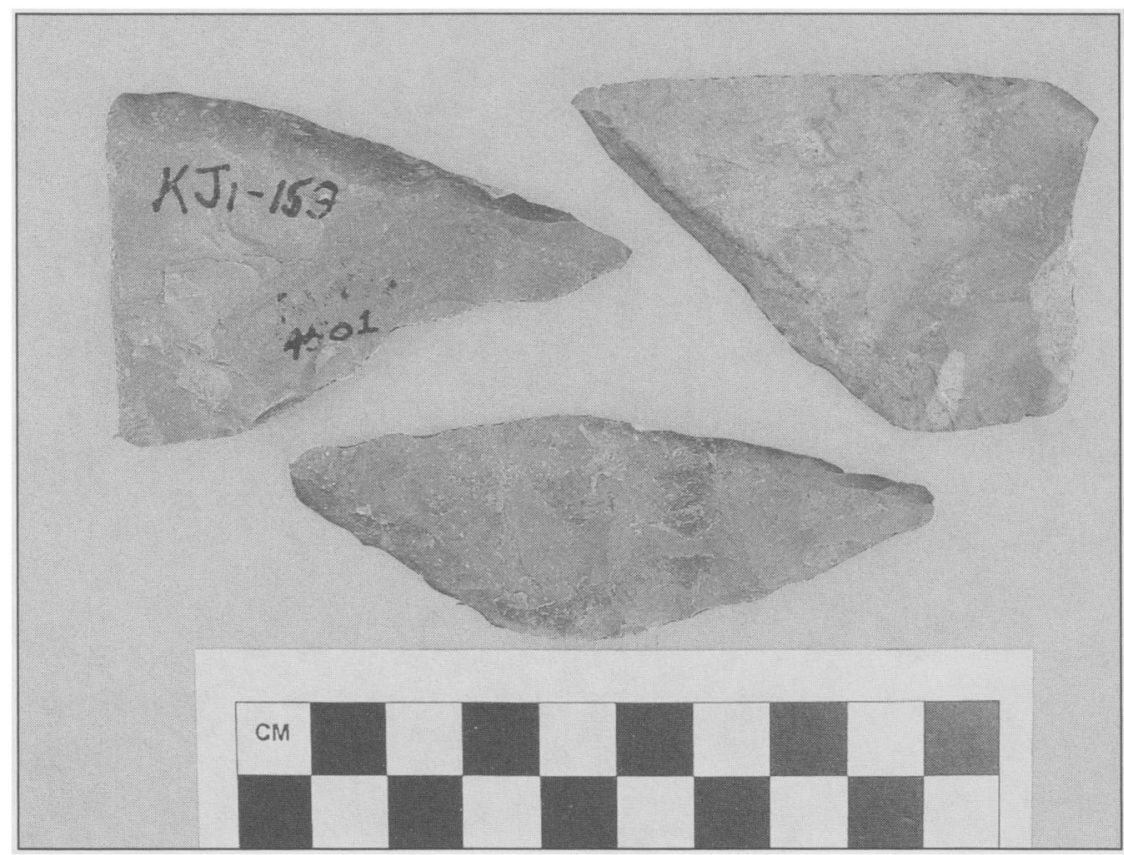

Figure 7 Examples of beveled knife and knife fragments from the White Rock site.

poseful sharpening of alternating edges of bifacial (often ovate) knives as they become dull from use, resulting in an increasingly diamond-shaped knife with multiple cutting edges. Many of the artifacts with beveled edges from the White Rock site are fragments, but opposite and adjacent edges are often alternately beveled as in the case of diamond-shaped (Harahey) knives (Figure 7). This suggests that these likely served as cutting edges rather than backing.

Three of the Niobrara jasper bifaces in the White Rock site assemblage are waisted or have two shallow side notches. These notches are often simply formed by the removal of one or more large flakes from the side, closer to one end than the other. One of these objects has a broad blade with a convex, relatively thin, bifacially flaked bit (Figure 8a). The sharpness of this edge may have made it appropriate for cutting or chopping. The poll end is also relatively thin and sharp, but is more roughly flaked. Another waisted biface has a flat poll end formed by an unmodified surface. The opposite or working end may have been broken and reworked as it is asymmetrical and fractured. The most protrusive portion of this end has a steep working edge that displays macroscopic wear suggesting a possible scraping function. The 


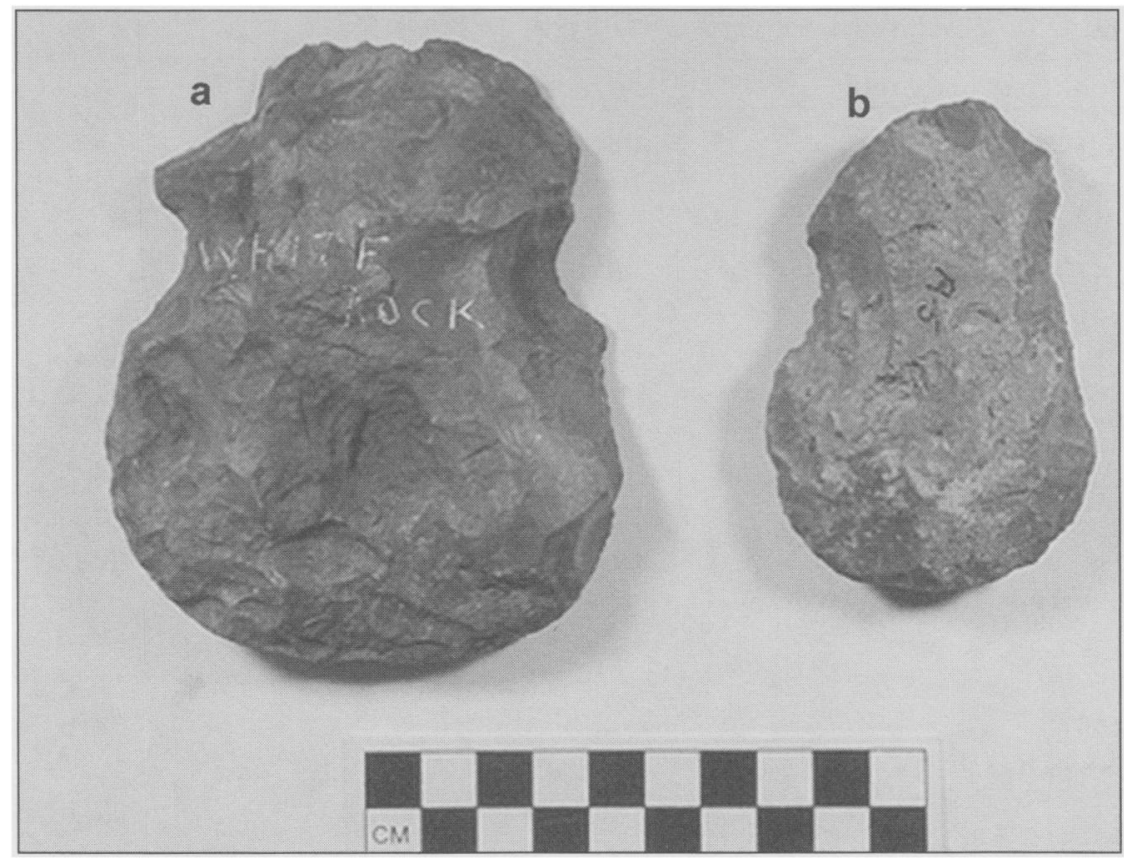

Figure 8 Two "waisted" bifaces of Niobrara jasper.

third waisted biface has an uneven poll formed mostly of natural surfaces and a convex working edge (Figure $8 \mathrm{~b}$ ). Evidence of bifacial retouch of the working edge is partially masked by heavy wear resulting in a battered and rounded appearance. This tool may have been used for chopping materials, such as wood, until it became dull from use. These tools do not show obvious signs of polish, which may result if used as hoes or other digging implements. Blakeslee, Peck and Dorsey's (2001:86-88) description of several Niobrara jasper celts from Glen Elder, a White Rock site along the Solomon River south of the White Rock locality, suggests a similar pattern of relatively crude hafted chopping implements. Bray (1991:105-106) also describes similar notched axes or hammers of chert from the Utz site in central Missouri.

\section{Unifaces}

A uniface is a tool, commonly made on a flake or blade that has been shaped on only one surface (Lurie and Jeske 1990:284-294). In addition to their unifacial form, these tools can exhibit unifacial or bifacial edge 
Table 2. Blank types for each artifact class.

\begin{tabular}{llrr}
\hline Tool Type & Edge Modification & $\#$ & $\%$ \\
\hline Bifaces & Bifacial & 141 & 63.8 \\
& Unifacial & 64 & 29.0 \\
& Uni/Bif & 16 & 7.2 \\
Unifaces & Bifacial & 1 & 6.3 \\
& Unifacial & 11 & 68.8 \\
Scrapers & Uni/Bif & 4 & 25.0 \\
Triangular Points & Unifacial & 242 & 97.6 \\
& Uni/Bif & 6 & 2.4 \\
Notched and Stemmed Points & Bifacial & 25 & 86.2 \\
\multirow{3}{*}{ Spokeshaves } & Unifacial & 1 & 3.4 \\
& Uni/Bif & 3 & 10.3 \\
Retouched Pieces & Bifacial & 3 & 75.0 \\
& Uni/Bif & 1 & 25.0 \\
& Unifacial & 7 & 77.8 \\
& Uni/Bif & 2 & 22.2 \\
& Bifacial & 17 & 10.3 \\
Utilized Pieces & Unifacial & 141 & 85.5 \\
Utilized Core & Uni/Bif & 6 & 3.6 \\
\hline
\end{tabular}

modification from use or retouch. In some cases, unifaces do not exhibit a clear working edge. That is, some were not retouched or utilized, but may have been prepared as unifacial blanks for future tool use.

Sixteen unifaces were recovered from the White Rock site (Table 1). These form a small percentage (2.1 percent) of the tool classes. Half of the unifaces are complete. Three-quarters were formed on blades, while the others were formed on flakes (Table 2 ). The unifaces commonly exhibit unifacial (68.8 percent) or unifacial and bifacial edge modification (25.0 percent) (Table 3).

Two general kinds of unifaces are recognized in the White Rock lithic subassemblage. Nine (56 percent) are very similar to utilized or retouched flakes or blades, although they may have received some additional general shaping as evident from at least one flake not originating from the edge of the artifact. These meet the minimum requirements for a uniface but do not exhibit significant modification. Most have been used or unifacially retouched along one edge. In one instance, two lateral edges are retouched, 
and another retouched piece appears to have been reworked several times, resulting in an evenly and steeply retouched edge.

The remaining unifaces ( 7 , or 44 percent) exhibit more extensive shaping and likely served as knives or side scrapers, as indicated by one or more evenly retouched edges. One especially thin distal flake fragment has invasive and marginal edge retouch on both lateral edges and the end. Another uniface formed on a flake has two marginally retouched edges and a ground or heavily worn edge adjacent to the striking platform of the original flake.

\section{Scrapers}

Scrapers are tools with one or more steep working edges (Goatley 1995:147). Edge angles are commonly greater than 50 degrees (cf., Andrefsky 1998:193) although tools with lower edge angles (30-50 degrees) may also be classified as scrapers based on general form (outline) and high degree of edge crushing and bright polish along the working end or edge (Benn 1991:37). It should be noted that in this study scraper identification was based on arbitrary identification of edge steepness, rather than on measured angles. Use-wear (crushing) was identified macroscopically.

Two hundred forty-eight scrapers were recovered from the White Rock site. This is the most abundant chipped stone tool type within the study sample, making up more than one quarter of the lithic subassemblage and one-third of the chipped stone tools (Table 1). All but two scrapers have a unifacial form, one is bifacial and the other is edge modified. The majority (79.4 percent) were formed on blades while the remainder (20.6 percent) were made on flakes (Table 2). As is expected for scraping tools, nearly all (97.6 percent) in this assemblage exhibit unifacial edge modification (Table $3)$. The 186 complete scrapers range in length from $18-119 \mathrm{~mm}$ long with an average of $49.2 \mathrm{~mm}(S=17.9)$. These tools were made from both Niobrara jasper (55.6 percent) and Flint Hills cherts (33.5 percent).

Although various studies of scraper function suggest these tools could be and were used on a variety of materials (e.g., wood, hide, bone, antler) and with different actions (Andrefsky 1998:193-194), it is assumed that most of the scrapers from the White Rock site were used primarily to clean and work hides, especially from bison. Unmodified bison bone is abundant at White Rock sites and wood was probably of limited availability. Scrapers generally started out as long blades, but as they were used, their working edge became dull and needed to be sharpened again. After repeated use in this manner, scrapers would shorten to what are often call 'thumbnail scrapers' and be too short for further use. If we arbitrarily identify exhausted 


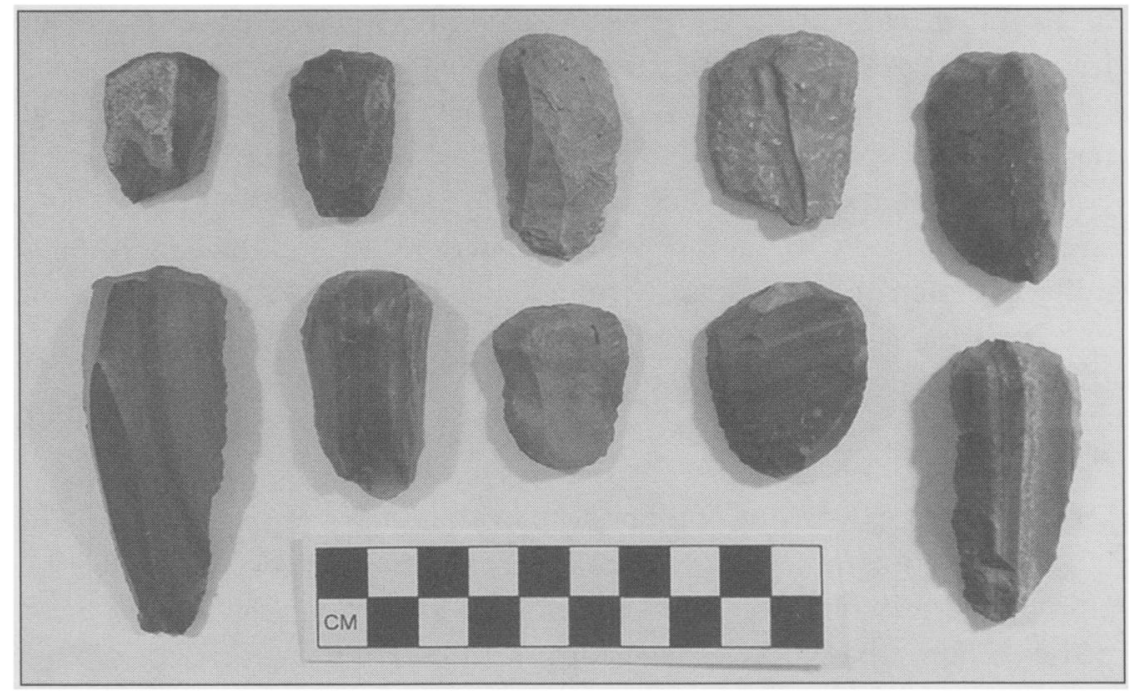

Figure 9 Sample of plano-convex end scrapers from the White Rock site.

scrapers as less than two centimeters in length, only two of the complete end scrapers from this site fall into this category. This suggests that scrapers were frequently abandoned before they became unusable. This might suggest that quality chipped stone resources were abundant enough to not require careful curation and recycling of those materials.

To further describe the variability among the scrapers at the White Rock site, we classified them according to placement of working edge(s). The edges and ends of each scraper were inspected for retouch and macroscopic evidence of wear (i.e., crushing). Working edges were defined based on the presence of both. It is possible, however, that edge preparation may be related to hafting, rather than use. Without microscopic use-wear analysis, it was impossible for us to identify polish or other wear patterns associated with hafting. Instead, we arbitrarily defined hafting preparation as retouch without obvious evidence of wear that extends approximately $10 \mathrm{~mm}$ or more from the proximal end along one or more lateral edges.

Nearly one-third (31 percent) of the scrapers are end scrapers, sharing the classic plano-convex form (Figure 9). More than half of the scrapers appear through macroscopic inspection to have been used along one or both of the lateral edges in addition to the end (end and side or distal-lateral scrapers). The remainder are single or double-sided scrapers that show no evidence of retouch along the distal end. These do not fit the classic end scraper description, but were assigned to this category due to crushing along 
the steep lateral edges. The presence of diverse forms of scrapers, judging from placement of the working edge, shows that the inhabitants did not rely on a single scraper form, rather a variety that suited individual, and potentially varied tasks.

It is unclear whether any of these scrapers were hafted for use. Using our criteria, it appears that few were formally prepared for hafting. Retouch along the edges near the proximal end of 27 , or 10.9 percent of the scrapers is suggestive of hafting preparation. To date, scraper handles (for instance, of bone or antler) have not been identified in White Rock assemblages.

\section{Triangular Points}

This class of chipped stone tools is commonly referred to as unnotched (Fresno or Madison) arrow points because of their small size (less than 5 cm long) and triangular (pointed) form. Hollinger (1993:74-75) refers to similar objects from the OT site as small triangular bifaces rather than projectile points in order to acknowledge that some of these artifacts may have been used as knives, scrapers, or gravers. Although we recognize the possibility of multiple functions for these tools, we prefer to use the term points rather than bifaces, since not all of these tools have a bifacial form. In some instances, they were formed through unifacial retouch of a flake or blade.

Twenty-nine unnotched points made from both Niobrara jasper and Flint Hills cherts were recovered from the White Rock site (Table 1, Figure $10)$. The majority (19, or 65.5 percent) are bifacial, although unifacial ( 7 , or 24.1 percent) and edge retouched (3, or 10.3 percent) forms also are present. The bifacial points were invasively flaked on each surface such that it is impossible to tell whether they were produced from a blade or flake. The edges of the White Rock points were frequently bifacially retouched ( 86.2 percent), although some (10.3 percent) included both bifacial and unifacial modification (Table 3). Only one triangular tool was formed solely by unifacial retouch of a single edge of a possible blade. This tool is larger than the other points and exhibits relatively steep edge retouch, suggesting it may have served a different function, perhaps scraping. The remaining sixteen points range in length from 15.3 to $29.9 \mathrm{~mm}$ (mean $=21.7 \mathrm{~mm}$ ) and have straight to slightly concave bases.

\section{Notched and Stemmed Points}

Goatley (1995:152-153) used the term 'nontriangular projectile points' for those tools from the Tremaine site that differ from the more typical Oneo- 


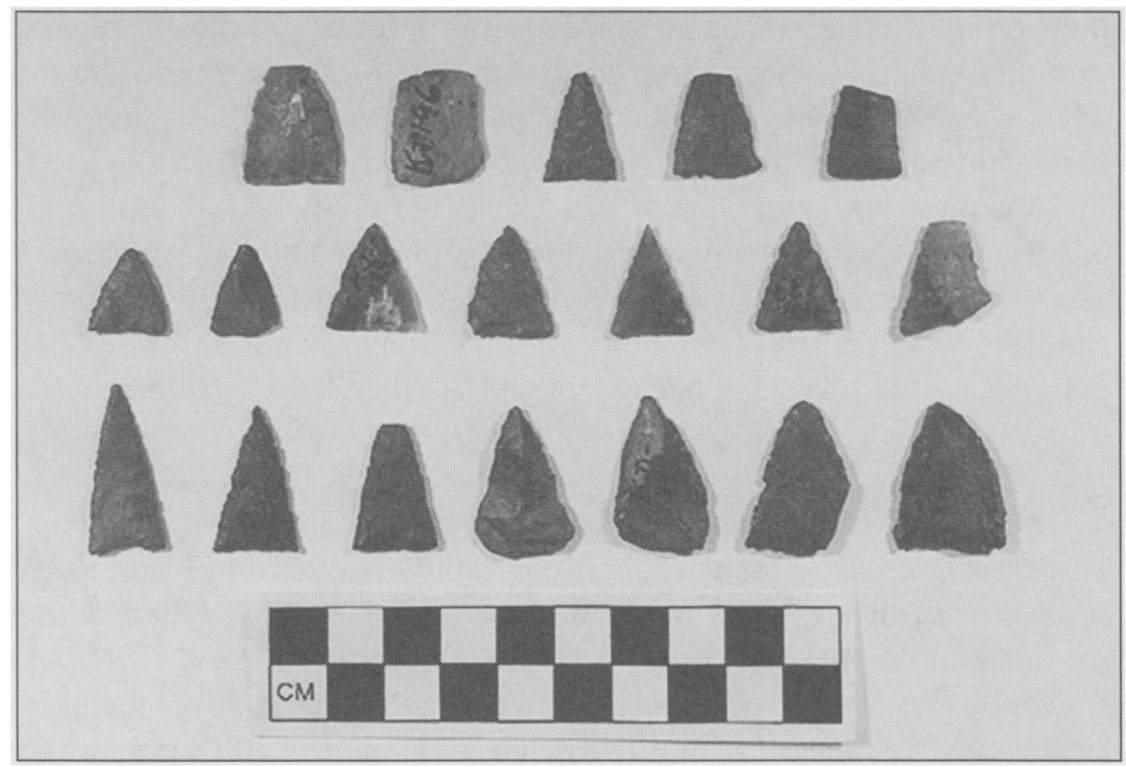

Figure 10 Sample of unnotched triangular points from the White Rock site.

ta arrow points, largely because they have a discernable hafting element or nontriangular form. Hollinger (1993:76-77) classified similar artifacts from the OT site as stemmed or side-notched bifaces. Given that the White Rock assemblage includes both triangular and nontriangular points with notches or a stem, we have chosen to simply classify these as notched and stemmed points.

The most anomalous point in the study assemblage is a relatively large (56.9 mm long, $24.3 \mathrm{~mm}$ wide, and $10.3 \mathrm{~mm}$ thick), stemmed biface (Figure 11d). It is made of an unidentified opaque chert that is pink with a blackened tip and lateral edge. The coloring and potlids at the tip of the point indicate the material had been heated. This point does not match late prehistoric styles and may represent recycling of an earlier point. It is not unusual to find other point styles at Oneota sites in small numbers. Hollinger (1993:77) noted three pre-Oneota stemmed and side-notched bifaces in the OT assemblage. Ten nontriangular points were recovered from the Tremaine site (Goatley 1995:152-153). Blakeslee and others (2001:86) indicate that three pre-Oneota points were found in the Glen Elder assemblage. The lack of evidence for earlier components at the White Rock and OT sites suggests that these points were recycled by the Oneota occupants of these sites. The nontriangular points from the Tremaine site may be associated with an earlier Late Archaic to Middle Woodland occupation that ap- 


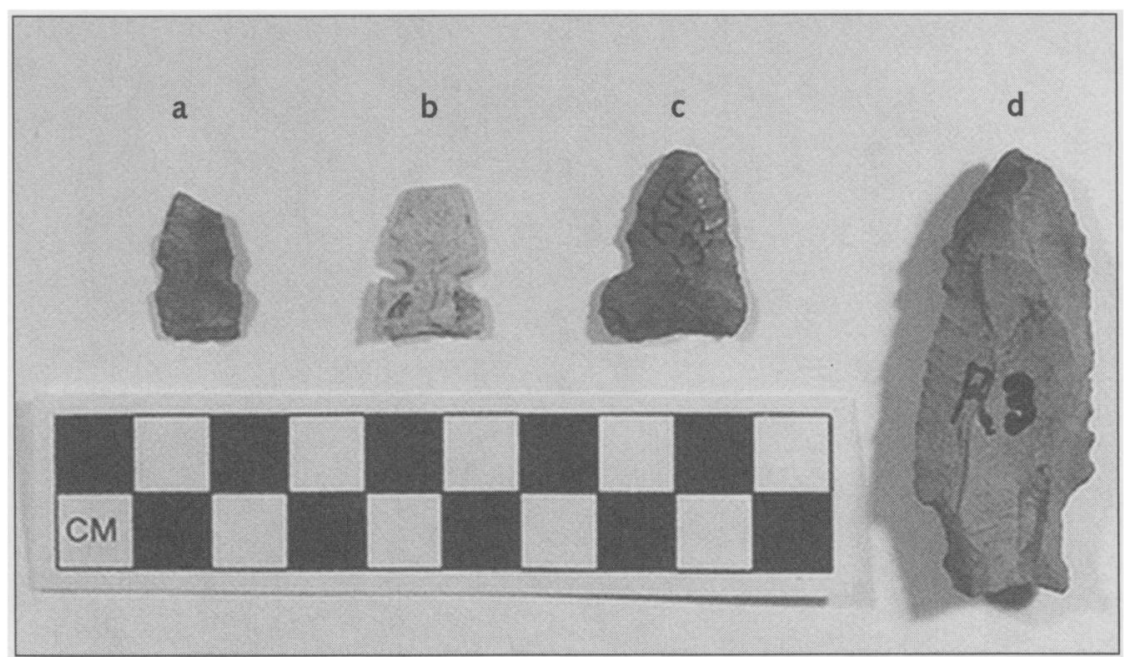

Figure 11 Sample of notched and stemmed points, including (a) a shallowly side-notched arrowpoint made from a thin flake of Niobrara jasper, (b) a side-notched arrowpoint made of an unidentified white chert, (c) a single side-notched arrowpoint made of heat-reddened Niobrara jasper, and (d) a stemmed projectile point made from an unidentified chert that has been heated.

pears to be represented in one portion of that site (Penman and Hamilton 1990, cited in Goatley 1995:152).

The remaining three points in the White Rock assemblage are similar to the triangular points from this site, although they appear to be side-notched. The first was made from a small, thin flake of Niobrara jasper and shows little evidence of modification (Figure 11a). Although the tip is missing, it is apparent that the flake had a generally triangular form. One edge exhibits minimal alternating unifacial retouch, while the base has marginal bifacial retouch. Shallow notches have been formed through fine unifacial retouch on opposite edges of this retouched flake. This artifact may have served as an expedient arrow point.

Two other probable arrow points are small triangular bifaces. One is clearly side-notched with well-defined and generally symmetrical notches and a slightly concave base (Figure 11b). It is made from a white chert that may be Niobrara jasper. As discussed below, this style of side-notched arrow point is not typically found in Oneota assemblages, except occasionally in those assigned to the White Rock phase. This form is more typical of the generally contemporaneous or slightly earlier Central Plains tradition. The other small arrow point is made of heated (reddened) Niobrara jasper. It has a single unifacial notch (possible plow or shovel scar?) (Figure 11c). 


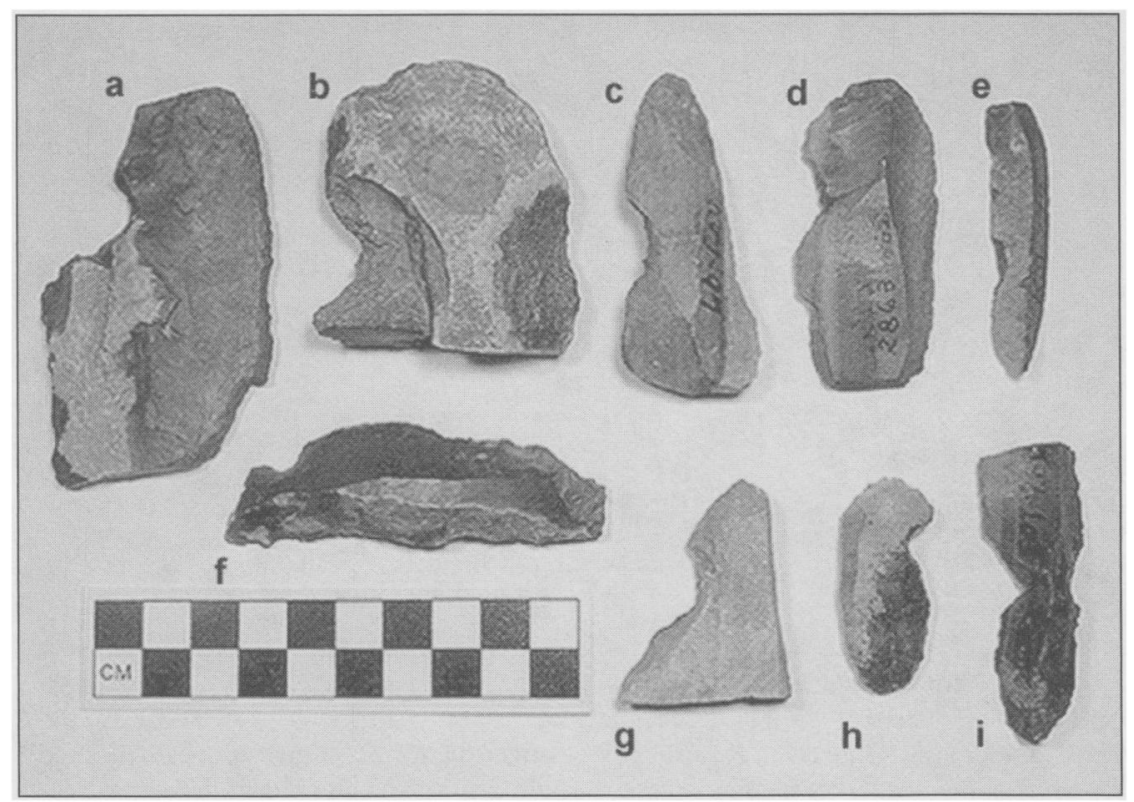

Figure 12 Spokeshaves included in the White Rock site assemblage.

\section{Spokeshaves}

Nine spokeshaves or purposely-notched artifacts were identified in this assemblage (Table 1; Figure 12). Since post-depositional activities (e.g., plowing, excavation, or other forms of site disturbance) can damage artifacts and form notches, it is often difficult to macroscopically discern whether notches were formed intentionally or through use. We classified those artifacts with notches that appeared to have been retouched or showed obvious signs of crushing or other macroscopic wear as spokeshaves. This retouch or use wear is generally unifacial. The maximum diameter of the notches on the spokeshaves in this collection ranges from about 7 to nearly $19 \mathrm{~mm}$. Most of the notches are rounded, although two are V-shaped. In some instances the notches are along the edge of a multi-purpose tool that has one or more additional working edges.

Two of the spokeshaves were formed on thin tabular pieces of Niobrara jasper that are now fragments of those original pieces. The notch on one of these artifacts is within a broken portion of the piece (Figure 12a). The lateral edges of this same piece are marginally retouched on opposite faces, forming a multifunctional tool or possible backing. Another tabular fragment not only has a notch but a small graver that appears to have 
been formed from bifacial retouch (Figure 12g). Gravers are found in other Oneota assemblages, including the Glen Elder assemblage (Blakeslee et al. 2001:91), and are sometimes part of multipurpose tools, such as the spokeshave-graver in this assemblage. One edge of this tool appears to be a natural fracture plane. One portion of this edge consists of poor quality chert that grades into cortex. It is smooth as if polished for backing or through use.

Six spokeshaves have notches along the lateral edge of a blade. All, except one, are Niobrara jasper. The latter is made from Flint Hills chert. Two of the Niobrara jasper blade spokeshaves have V-shaped notches. In one instance this notch is on the edge opposite a very shallow rounded notch (Figure 12i). In another case, the $\mathrm{V}$-shaped notch is along the lateral edge of an end scraper near the distal working end (Figure 12h).

\section{Retouched Pieces}

Retouched pieces consist of purposely-modified flakes, blades, or tabular pieces. Retouch is arbitrarily identified as at least three contiguous flake scars extending along at least $0.5 \mathrm{~cm}$ of the tool's edge and at least $1.0 \mathrm{~mm}$ onto the body of the piece from its edge (Lurie and Jeske 1990:285).

One hundred sixty five artifacts (17.1 percent) in the study assemblage are defined as retouched pieces (Table 1 ). More than half (54.6 percent) consist of retouched flakes, while nearly 40 percent are retouched blades (Table 2). Approximately 5 percent are tabular pieces with one or more retouched edges. A single retouched piece was produced from a cobble of Niobrara jasper and another was formed from a fragment of petrified wood. Edge retouch was commonly unifacial (Table 3 ). These pieces are extremely variable in form and include different kinds of working edges that would have been suited to different tasks, including cutting, scraping, and engraving. Three retouched flakes exhibit unifacial flaking along the lateral edges of the distal end of the flake, producing a projection that appears to have been used as a graver. As noted for the spokeshave-graver described above, gravers are commonly found in Oneota assemblages and could have been used for engraving, scoring or shaping bone, wood or other resilient materials. Microscopic use-wear analysis is needed to identify the function of these and the other retouched tools.

\section{Utilized Pieces}

Utilized pieces are pieces of debitage that appear to have been utilized with little or no preparation of the working edge. Signs of use-wear were identified 
macroscopically and include microflaking, battering, grinding, polishing, or rounding that extends less than $0.5 \mathrm{~cm}$ along the edge of the piece and no more than $1.0 \mathrm{~mm}$ onto the body of the piece (Lurie and Jeske 1990:285). We have included in this tool class one utilized Niobrara jasper core. This artifact appears to have been used, possibly for scraping, after it had been exhausted as a core.

Fifty-three utilized pieces (including the utilized core) were recovered from the White Rock site (Tables 1 ). In addition to the utilized core are 27 blades and 25 flakes showing signs of use (Table 2). All exhibit unifacial edge wear (Table 3). Many of these served as expedient tools overlapping in function with more formalized tools, such as knives and scrapers.

\section{Discussion}

This study provides a general description of the variability of chipped stone tools and debris from the White Rock site. Application of the above-described classification system allows us to compare assemblages, especially those for which a similar classification system has been used (e.g., OT site [Hollinger 1993], Tremaine site [Goatley 1995]). Although frequencies of different tool types can be compared using this system, interpretations based on these comparisons should be tested against other data given the differences in sample sizes and the areas from which they are drawn. The White Rock lithic subassemblage is relatively small due to the limited nature of the early investigations of this site. This sample is derived from a small, excavated portion of the White Rock site and arbitrary surface collections. A similar assemblage was collected from Glen Elder, another White Rock phase site in nearby Mitchell County, Kansas (Blakeslee et al. 2001; Marshall 1969). Excavation procedures used in the 1930s at these two sites likely did not include systematic screening, and surface collecting often results in high grading or selection of the largest, most visible and patterned tools. As a result of limitations with this sample, the ideas developed herein will benefit from further analyses.

One observation resulting from this study is that less than one quarter of the lithic subassemblage is debitage, a small percentage given the amount of debris produced in the manufacture of chipped stone tools. A very low debitage frequency is also noted in the Glen Elder assemblage (Blakeslee et al. 2001). Debitage frequencies closer to 97-99 percent are typical of late prehistoric Oneota sites in southwestern Wisconsin (Hollinger 1993, Goatley 1995). The low frequencies in these two White Rock assemblages may be due to several factors. As noted above, one may be the field methods 
applied in the 1930s, with a possible bias towards larger and more formal tools. Another possibility may be that chipped stone tool production at this site was limited to the final stages of production and retouching of blanks, preforms, and tools or, at least, limited knapping within the areas excavated and surveyed in the 1930s. The low number of recognizable cores suggests that primary reduction was not a common activity at least in this portion of the site. Initial reduction may have occurred elsewhere, perhaps closer to quarry areas some distance from the site. A complementary explanation for the low frequency of waste debris is that the White Rock inhabitants utilized or reworked many of the larger pieces of debitage into tools. According to the classification scheme employed herein, these pieces would be identified as tools (including utilized or retouched pieces). Given the large number of informal tools present in this assemblage, this latter explanation appears plausible, but does not exclude the other explanations.

No matter how frequent the debitage, it is clear that many of the chipped stone tools from the White Rock site were formed through limited expenditure of time and energy. A quick glance at the White Rock chipped stone tool subassemblage reveals that many of the tools do not exhibit a standardized form or extensive flaking. If we use the identification of blank type as a measure of tool formality, nearly three-quarters of the chipped stone tools in the White Rock assemblage are informal. Seven percent of the tools are utilized pieces that show no preparation beyond obtaining the blank (e.g., producing or picking up a flake or blade) (Table 1). More than 22 percent of the tools consist of retouched flakes, blades, and tabular pieces. The general form of these was determined by characteristics of the blank. The remaining tools exhibit more symmetry and patterning. However, many are similar to retouched pieces in that they were formed from debitage or tabular pieces through minimal flaking. This is evident in the ability to identify the original blank because extensive flaking did not obliterate its form. Scrapers, for example, which make up one-third of the tools, were made from blades and flakes with minimal unifacial retouch along one or more of the edges (Table 2). Unifaces and spokeshaves were also formed on blades, flakes, and tabular pieces with minimal modification. Bifaces and points generally exhibit more extensive and invasive flaking, although a number appear to be informal in that preparation did not destroy the original blank's form. For example, 16.3 percent of the bifaces were obviously formed from tabular pieces of Niobrara jasper. The lenticular nature of this raw material allowed flintknappers to make relatively thin tools with limited invasive flaking. It is clear that the White Rock site occupants commonly expended only enough effort to form a functional edge. Additional modifications to assist 
with hafting were not considered necessary. Instead, effort may have been directed towards careful selection and transport of raw materials suited for tool manufacture and producing usable blanks.

Observations regarding debitage form and blank type provide clues to the kind of lithic technologies used by the White Rock peoples. The frequent production of blades, as evident from their relatively high frequency among the debitage (19 percent) and tool blanks (42 percent), suggests purposeful manufacture of these elongated pieces. Those people who utilized the Glen Elder site also showed a preference for making blades. Not only were tools (especially scrapers) formed on blades, but large and small blades were left unmodified for later use or used without retouch (Blakeslee et al. 2001:88-89). Blades were also produced and used at the Leary and Dixon sites, late prehistoric western Oneota occupations (Finney and Crawford 1999). Comments about scrapers from the Fanning and Utz sites suggest blades continued to be used at later western Oneota sites (Bray 1991:113; Wedel 1959:155-157). Unfortunately, few published reports indicate the frequency of blades and blade tools in Oneota assemblages. Albeit based on limited data, it appears that Oneota peoples living on the western prairies and plains may have used blades or lamellar flakes more extensively than their eastern relatives. This hypothesis is based in part on documented observations of very few blades in the large lithic assemblages from late prehistoric Oneota sites in southwestern Wisconsin (Goatley 1995:150; Hollinger 1993:81). We recommend that future analyses of Oneota assemblages include documentation of the frequency of production and use of blades or lamellar flakes. Likewise, focused technological studies of the lithics in western and other Oneota assemblages are needed to provide additional insight into how blades were produced.

It is clear from the analysis of the White Rock site lithics that blades were most useful in the production of scrapers (79.4 percent formed on blades) (Table 2). Elongated flakes are ideal for these tools due to their natural plano-convex form and length. The latter attribute allows for frequent sharpening of the distal working end, as well as providing a long lateral working edge. The edges of blades were also modified to form spokeshaves and cutting or scraping edges (cf. Blakeslee et al. 2001:88-89). One possible explanation for the lower percentage of blades among the unmodified materials versus the tools may be that blades, more often than flakes, were specifically selected for scrapers and other tools, thus, not discarded as frequently as waste materials.

The size of scrapers in this study assemblage compares favorably, although with some variation, with those recovered from the White Rock 
site during later expeditions and from other White Rock phase sites. The scrapers recovered in 1956 from the White Rock and nearby Intermill and Warne sites did not exceed the length of those in our study assemblage, except in one instance (Neuman 1963:267-268, 272-273, 283-284). That scraper, measuring $130 \mathrm{~mm}$ long, was one of 409 scrapers recovered from the Warne site. This and other relatively large scrapers from the Warne and White Rock sites exceed the length of scrapers recovered from the Glen Elder site (Blakeslee et al. 2001:90-91). However, the mean length (55.1 mm) of scrapers from Glen Elder, is slightly higher than the mean $(49.2 \mathrm{~mm})$ derived from this study. As suggested by Blakeslee and others (2001:91), the greater mean length for scrapers from the Glen Elder site may be due to its short-term use and the disposal of still functional tools. Frequent and potentially longer-term occupation of the extensive White Rock site may have resulted in somewhat more intensive use of scrapers. The average length of scrapers from the Tremaine, OT, and nearby Filler sites is substantially shorter (24.6-34.9 mm) (Goatley 1995:148). Longer occupation of these and other Oneota sites, perhaps combined with limited availability of sizable lithic materials suited for the manufacture and use of scrapers, may explain the generally smaller scrapers recovered from those sites (Blakeslee et al. 2001:91).

In addition to numerous scrapers, the White Rock site has an abundance of bifaces. More than 29 percent of the chipped stone tools from the White Rock site are bifaces (Table 1). This is much higher than other Oneota assemblages, including the otherwise very comparable Glen Elder assemblage. This may be due in part to the large size and apparent visibility of the bifaces. Many of those included in this study assemblage were part of the A.T. Hill collection and were probably surface finds from cultivated fields. Nonetheless, the abundance of bifaces, many of substantial size, seems to be one characteristics of the White Rock (and probably the nearby Warne) site.

The bifaces from the White Rock site overlap the range of sizes of bifaces from other Oneota sites, but are also larger in many cases. For example, the maximum length, width, and weight measurements of bifaces from Area $\mathrm{H}$ of the Tremaine site in the LaCrosse area of Wisconsin do not exceed 109 $\mathrm{mm}, 97 \mathrm{~mm}$, and $354 \mathrm{~g}$, respectively (Goatley 1995:148). The maximum measurements of complete bifaces in the White Rock assemblage are 365 $\mathrm{mm}, 130 \mathrm{~mm}$, and $1126 \mathrm{~g}$, respectively. Thickness measurements are very similar and range in both assemblages between 4-42 $\mathrm{mm}$. The differences between these assemblages are likely a factor of raw material. Niobrara jasper, the most abundant raw material in the White Rock assemblage, can 
be extracted from natural outcrops in large, lenticular pieces (Stein 2004). Although the White Rock site lies some distance from the source area of this material, it was brought to the site in fairly large pieces as is evident from the sizes of some of the bifaces. The bifaces at the Tremaine site were made from a wider variety of materials, including Prairie du Chien group cherts, Silicified Sandstone, and Grand Meadow chert (Goatley 1995:158, Table 8.7). These materials appear to have been available in much smaller pieces and likely were not as abundant.

Niobrara jasper bifaces have also been recovered from the nearby Warne site (also White Rock Oneota). Relatively large bifaces ("chipped celts" and "blanks") were recovered during excavations at the Warne site as part of the River Basin Surveys in 1956 (Neuman 1963:284-285). George Warne, former owner of this site, also collected bifaces and other artifacts from this site. A number of these are preserved in the Floyd and Ada Jane Broceus Schultz Collection curated by the University of Kansas Museum of Anthropology (KUMA). Four of the largest bifaces purchased by Floyd Schultz from George Warne weigh between 956 and 11,095 g (data on file at KUMA). These are not especially thick (19-33 mm), but measure between 244-340 mm long and 118-134 mm wide. Very large worked pieces of Niobrara jasper have also been found great distances from the source area and the Warne and White Rock sites, including as far as northeastern Kansas (Stein 2004:35-40; Thies 2002, 2003).

The form and function of the White Rock bifaces is varied. Although many are ovate, waisted and other forms also exist. No elliptical bifaces, such as found at certain Midwestern Oneota sites (Goatley 1995:1148), were recognized in this assemblage. It is difficult to ascertain the function of many of the White Rock bifaces based solely on their form. Several appear to have been notched for hafting and may have served as celts or axes. Others are thin with sharpened or beveled edges suggesting use as knives. Beveled knives are not common at Oneota sites in the Midwest. However, they occur with regularity at White Rock Oneota sites, including the White Rock, Warne, Intermill, Glen Elder, and Meek sites (Blakeslee et al. 2001:86; Logan 1995; Neuman 1963; Ritterbush and Logan 1991:90). Beveled knives are also present at the Leary site, a late prehistoric Oneota site in extreme southeastern Nebraska (Hill and Wedel 1936:50-51). Although bifacial knives are noted at the generally contemporaneous Dixon site in northwestern Iowa, those with beveled edges are not common. Harvey (1979) did not record any in the assemblage from this site, but Finney and Crawford (1999:57) found three in the assemblage recovered in 1994. Beveled knives are also present in other western Oneota assemblages, including from the Utz, Fanning, 
and Blood Run sites, which represent later Oneota (post-1400) occupations (Bray 1991:107; Harvey 1979:146-157; Wedel 1959:155). The prevalence of beveled knives at White Rock and other western Oneota sites is believed to be indicative of extensive bison hunting (cf. Sollberger 1971).

As described above, 29 unnotched points were recovered from the White Rock site (Table 1, Figure 10). These include bifacial and unifacial forms, as well as edge-modified flakes. Comparable small, triangular unnotched points predominate at Oneota sites across the central portion of the United States (Henning 1998:349; Hollinger 1993:74-75; Morrow 1984:80-81). In overall outline and size, these tools are similar to point preforms and arrow points found at sites in the Central Plains that are contemporaneous or slightly earlier than the White Rock Oneota occupation of this region. The Central Plains tradition points, however, are commonly side-notched (Owada and Ritterbush 1999). Side-notched arrow points occur in other Oneota assemblages, albeit in very small numbers. As noted above, three small side-notched points are included in this study sample. Two others were recovered during later investigations of the White Rock site (Logan 1995:67-68; Neuman 1963:267). Other reports of side-notched arrow points in White Rock assemblages include nine from the nearby Warne site (Logan 1995:68; Neuman 1963:282), two possible notched arrow points from the Glen Elder site (Blakeslee et al. 2001:86), and one from the Meek site (Ritterbush and Logan 1991:89). Other western Oneota sites that include notched arrow points are Leary (n=3; Hill and Wedel 1936:49) and Dixon ( $n=5$, although some of the latter are larger than most Oneota points; Harvey 1979:81). Occasional side-notched points are reported for Oneota sites in central Missouri (e.g., Utz; Bray 1991:101-103; Guthrey; Henning 1970:75-78) and central Iowa (e.g., Cribb's Crib site; DeVore 1990:63) and more rarely from sites to the east (e.g., Kingston; Straffin 1971:15). It is clear that notching was not a common Oneota practice. The few examples in Oneota assemblages may represent variability in how Oneota peoples formed or prepared these tools, curation of points made by other groups, or, at least potentially in the western prairies and plains, interaction with Central Plains tradition peoples.

The primary materials selected for chipped stone tool manufacture by the White Rock Oneota were Niobrara jasper and Flint Hills cherts. All tools that have a tabular form were made from Niobrara jasper, which commonly outcrops in thin lenses. Large numbers of bifaces (81 percent) were made from Niobrara jasper, including 36 formed from tabular pieces, suggesting the ease with which bifacial forms can be fashioned from this material. Although not as frequently, Niobrara jasper was also commonly used for 
scrapers (56 percent; 34 percent Flint Hills cherts). Both Niobrara jasper and Flint Hills chert flakes and blades were modified for tools or discarded during the flintknapping process. The overall preference for Niobrara jasper suggests more frequent movement to the west where this material outcrops (Logan 1995, 1998b; Ritterbush and Logan 2000). Nonetheless, the presence of Flint Hills cherts from the east also indicates travel in that direction.

The lithic utilization pattern of the Glen Elder Oneota varies from that found at the White Rock site. The Glen Elder assemblage includes a much higher frequency of Flint Hills cherts than Niobrara jasper. This is especially evident among scrapers where 86 percent of these tools are made from Flint Hills cherts, while only 14 percent are made from Niobrara jasper. In addition to the scrapers, 116 blades (which would have made excellent blanks for scrapers) were recovered from the Glen Elder site. The majority (98.3 percent) of these were of Flint Hills cherts. Blakeslee and others (2001) suggest that the Glen Elder site was a base camp occupied by a large group of people, but for a relatively short period of time. The high percentage of Flint Hills cherts suggests that its occupants came to the Glen Elder site from the east where they had visited chert outcrops in the Flint Hills (Blakeslee et al. 2001). This fits with the interpretation that White Rock peoples were moving between the Flint Hills and areas to the west, but with the Glen Elder assemblage representing movement from the east prior to occupying that site.

\section{Conclusions}

Through this study we hoped to add to the literature on Oneota lithic artifacts, further the use of a standardized descriptive classification system for Oneota chipped stone artifacts, test the Oneota affiliation of the White Rock phase, and discuss differences in the lithic subassemblage that may reflect Oneota adaptation to the western Plains. We have found that use of a modified form of the analytical system developed by Lurie and Jeske (1990) provides a useful means of describing chipped stone artifacts recovered from the White Rock site in the 1930s. Use of standardized and clearly defined classes also greatly facilitates comparisons between Oneota assemblages (cf. Hollinger 1993:73). We attempted this by comparing the White Rock site lithics with those from other western and Midwestern Oneota sites, especially the generally contemporaneous Tremaine and OT sites in southwestern Wisconsin for which similar recording systems were used. Despite the small size of the White Rock lithic subassemblage, it is apparent that stone tools similar to those in other Oneota assemblages were produced at this 
site. Clear similarities are seen in the form of the arrow points and in the prevalence of informal tools.

To facilitate the identification of informal (or "expediently manufactured") tools, we modified the Lurie and Jeske (1990) analytical system to include debitage form and blank type. By doing this we eliminated the class of 'blades' as a tool type. Instead blades were recorded as a specific form of debitage or as a blank form for tools. Analysis of tool form combined with blank type shows that the inhabitants of the White Rock site frequently used informal tools. Rather than forming tools through extensive bifacial flaking, chipped stone tools were commonly produced by minimally retouching blades, flakes, and tabular pieces. This is evident in the frequency of retouched and utilized pieces. It can also be seen through analysis of the blank form of other tools, such as scrapers, unifaces, spokeshaves, triangular points, and even bifaces. The latter two tool types were formed as both formal (fully bifacial) and informal (incompletely modified blank) tools. These data support the interpretation that the White Rock people relied on an informal chipped stone tool technology that made extensive use of both blades and flakes, as well as naturally formed tabular pieces. Informal chipped stone tools are common at Oneota sites throughout the Midwest and Plains (Finney and Crawford 1999:51; Goatley 1995:162; Jeske 1992).

By recording blank type, it became evident that the White Rock people produced both flakes and blades. Blades are present in high frequencies at the White Rock, as well as at the Glen Elder sites (Blakeslee et al. 2001:8889), suggesting that blade technology was important to these westernmost Oneota. It is postulated that this is a reflection of the size and quality of available lithic materials and the usefulness of blades in the production of tools that facilitated a Plains adaptation.

The White Rock Oneota clearly had access to quality lithic materials, namely Niobrara jasper and Flint Hills cherts, which occur in quantity as large lenses or nodules and are easily obtained from outcrops in northwestern and eastern Kansas, respectively. The White Rock site is not located near these outcrops, yet the abundance of large chipped stone tools (and discard of usable tools) suggests that the White Rock site occupants had easy access to these materials. Other data, especially the abundance of bison bone, lack of evidence for substantial shelters, and distribution of White Rock phase sites in north-central Kansas and southern Nebraska suggest that the White Rock Oneota were mobile, traveling through the heart of the Central Plains from base villages along White Rock Creek (Logan 1998a, 1998b; Ritterbush and Logan 2000). These travels took them into the northern Flint Hills and into northwestern Kansas where they obtained these quality lithic 
materials. Much of the initial production of tools may have occurred at the source areas as the limited quantity of debitage and few cores at the White Rock, as well as the Glen Elder, sites hints that initial stone tool production was limited at these sites. We suggest that much of the material may have been transported to the White Rock site in the form of bifacial blanks that could be worked into tools or used as cores. One difference between the White Rock lithic subassemblage and other Oneota assemblages lies in the greater overall size of bifaces. (The nearby Warne site also includes numerous large bifaces.) As noted above, this is likely a reflection of raw material availability and form. Niobrara jasper, which was readily available to only the westernmost Oneota, is easily formed into large bifacial blanks due to its common natural form. A call is made for formal use-wear analysis of the abundant and often large bifaces at the White Rock (and Warne) sites(s) to determine their function and whether some of these served as bifacial cores.

Another variation between the White Rock site chipped stone subassemblage and those from other Oneota sites, especially those in the Midwest, is the abundance, size, and variety of scrapers. The high incidence of scrapers can be measured using Hall's (1962) scraper-point index. Boszhardt and McCarthy (1999) have used this index, figured as 100 times the ratio of scrapers to points, to compare Oneota sites. The western Oneota sites have high scraper-point indices suggesting extensive hide working. The scraperpoint index figured for the White Rock site based on this study assemblage is 855 (248 scrapers, 29 unnotched arrowpoints), comparable to that calculated for the Glen Elder site (870; Blakeslee et al. 2001:89). Midwestern Oneota assemblages have much lower indices (Boszhardt and McCarthy 1999). The high incidence of scrapers in White Rock phase and other western Oneota assemblages, combined with other data (e.g., abundant bison remains) indicating frequent hunting of bison, no doubt reflects extensive working of hides. It takes a significant number of scrapers to prepare hides, especially those of bison. This may explain in part the production of blades, whose form is well suited for end scrapers that can be repeatedly sharpened and for informal knives used for cutting (hides as suggested by Blakeslee and others [2001:88-89]).

Another chipped stone tool form common at White Rock sites, less so at other western Oneota sites, but rare at eastern Oneota sites is the beveled knife. Like the abundance of scrapers, these tools are believed to indicate extensive butchering, presumably of bison.

As this study shows, analysis of chipped stone tools from the White 
Rock site reinforces the current interpretation derived largely from ceramic, faunal, and settlement data that White Rock archaeological remains represent the activities of Oneota migrants on the Plains where they became heavily dependent on bison hunting (Logan 1995, 1998a, 1998b; Ritterbush and Logan 2000). As discussed elsewhere, this adaptation likely was related to procurement, processing, and exchange of bison products, such as hides, dried meat, and certain bones (e.g., scapulae) for tools (Ritterbush 2002a).

\section{Acknowledgments}

We take this opportunity to thank those institutions, programs and individuals who facilitated this project and provided comments on an earlier version of this manuscript. Access to the 1930s White Rock site assemblage was made possible through a loan from the Kansas State Historical Society Archeology Lab. Support for the primary author while working on this analysis was provided by the Developing Scholars Program at Kansas State University under the direction of Anita Cortez. We express our sincere thanks to Bill Green, two other reviewers, and MCJA Editor Bill Lovis for their useful and insightful comments for our consideration in revising this article. Thank you for your time and effort in helping improve the reporting of this research.

\section{References Cited}

$\rightarrow$ Andrefsky, W. Jr.

1994 Raw-Material Availability and the Organization of Technology. American Antiquity 59:21-34.

1998 Lithics: Macroscopic Approaches to Analysis. Cambridge University Press, New York.

Auckly, A., R. Layman, A. Richter, and T. Roop

2000 Source Characterization of Lithic Raw Materials in Riley, Geary, and Pottawatomie Counties, North Central Kansas. Unpublished manuscript on file with the Kansas State University Archaeology Lab, Manhattan, Kansas.

Benn, D. W.

1991 The Christenson Oneota Site, 13PK407. Journal of the Iowa Archeological Society 38:16-55.

Bevitt, T. C.

1999 Life on the High Plains Border: Archeological Investigations of Three Late Prehistoric Habitation Sites in Southwest Kansas. The Kansas Anthropologist 20:1-106. 
Bevitt, T. C. and C. Garst

2003 The Proof is in the Pot: A Pilot Study of the Ceramics from some Plains Border Variant Sites in South-Central Kansas. Paper presented at the $25^{\text {th }}$ Annual Flint Hills Archaeological Conference, Topeka, Kansas.

$\rightarrow$ Blakeslee, D. J., M. Peck, and R. A. Dorsey

2001 Glen Elder: A Western Oneota Bison Hunting Camp. Midcontinental Journal of Archaeology 26:79-104.

Blasing, $\mathrm{B}$.

1984 Prehistoric Sources of Chert in the Flint Hills. Unpublished manuscript on file with the author.

$\rightarrow$ Boszhardt, R. F. and J. McCarthy

1999 Oneota End Scrapers and Experiments in Hide Dressing: An Analysis from the La Crosse Locality. Midcontinental Journal of Archaeology 24:177-199.

Bray, R. T.

1991 The Utz Site: An Oneota Village in Central Missouri. The Missouri Archaeologist 52:1-146.

Carlson, G. F. and C. A. Peacock

1975 Lithic Distribution in Nebraska. In The Lithic Source Notebook, edited by R. A. Thomas, Division of Historical and Cultural Affairs, State of Delaware, Milford.

Cooper, P. L.

1937 Field notes. Archeology Division, Kansas State Historical Society, Topeka, Kansas.

1955 The Archeological and Paleontological Salvage Program in the Missouri Basin, 1950-1951. Smithsonian Miscellaneous Collections 126(2).

DeVore, S. L.

1990 The Cribb's Crib Site (13WA105): The Archaeology and Ecology of an Oneota Village in the Central Des Moines Valley. Journal of the Iowa Archeological Society 37:46-87.

Fenenga, F. and P. L. Cooper

1951 Appraisal of the Archeological and Paleontological Resources of the Lovewell Reservoir, Jewell County, Kansas. Missouri River Basin Survey, Smithsonian Institution. Mimeographed report on file, Museum of Anthropology, University of Kansas, Lawrence.

Finney, F. A. and G. T. Crawford

1999 Chipped Stone Assemblage. In Bison Hunters of the Western Prairies: Archaeological Investigations at the Dixon Site (13WD8), Woodbury County, Iowa, edited by R. L. Fishel, pp 51-59. Report 21. Office of the State Archaeologist, The University of Iowa, Iowa City.

Fishel, V. C. and A. R. Leonard

1955 Geology and Ground-Water Resources of Jewell County, Kansas. Bulletin 115. University of Kansas Publication, State Geological Survey of Kansas.

Goatley, D. B.

1995 Chipped-Stone Analysis. In The Tremaine Site (47 Lc-95) by J. O'Gorman, pp. 145-164. Archaeology Research Series No. 3. State Historical Society of Wisconsin, Museum Archeology Program, Madison. 
Hall, R. L.

1962 The Archaeology of Carcajou Point. 2 vols. University of Wisconsin Press, Madison.

Harvey, A. E.

1979 Oneota Culture in Northwestern Iowa. Report 12. Office of the State Archaeologist, The University of Iowa, Iowa City.

Haury, C.

1984 Availability, Procurement, and Use of Chert Resources by Late Archaic Populations in the Southern Flint Hills of Kansas. Unpublished Master's Thesis, Department of Anthropology, University of Kansas, Lawrence.

Henning, D. R.

1970 Development and Interrelationships of Oneota Culture in the Lower Missouri River Valley. The Missouri Archaeologist 32:1-180.

1998 The Oneota Tradition. In Archaeology on the Great Plains, edited by W. R. Wood, pp. 345-414. University Press of Kansas, Lawrence.

Hill, A. T. and W. R. Wedel

1936 Excavations at the Leary Indian Village and Burial Site, Richardson County, Nebraska. Nebraska History Magazine 17(1):2-73.

Hollinger, R. E.

1993 Analysis of Lithics. In The OT Site (47 Lc-262), by J. O'Gorman, pp. 73-89. Archaeology Research Series No. 1. State Historical Society of Wisconsin, Museum Archeology Program, Madison.

$\rightarrow$ Jeske, R. J.

1992 Energetic Efficiency and Lithic Technology: An Upper Mississippian Example. American Antiquity 57:467-481.

Lamb, G. F.

1935 Field notes. Archeology Division, Kansas State Historical Society, Topeka, Kansas.

Logan, B.

1993 Archaeological Investigations in Lovewell Reservoir, Jewell County, Kansas, 1992. Project Report Series No. 79. Museum of Anthropology, University of Kansas, Lawrence.

1995 Phasing in White Rock: Archaeological Investigation of the White Rock and Warne Sites, Lovewell Reservoir, Jewell County, Kansas, 1994-1995. Project Report Series No. 90. Museum of Anthropology, University of Kansas, Lawrence.

$\rightarrow 1998 \mathrm{a}$ The Fat of the Land: White Rock Phase Bison Hunting and Grease Production. Plains Anthropologist 43:349-366.

1998b Oneota Far West: The White Rock Phase. The Wisconsin Archeologist 79:248267.

Logan, B. and W. E. Banks

1994 White Rock Revised: Archaeological Investigation of the White Rock and Warne Sites, Lovewell Reservoir, Jewell County, Kansas. Project Report Series No. 85. Museum of Anthropology, University of Kansas, Lawrence.

Logan, B. and J. G. Hedden

1992 Archaeological Survey of Lovewell Reservoir Jewell County, Kansas 1991. Project Report Series No. 77, Museum of Anthropology, University of Kansas, Lawrence. 
Lurie, R.

1990 Chipped-stone Assemblage. In At the Edge of Prehistory: Huber Phase Archaeology in the Chicago Area, edited by J. A. Brown and P. J. O'Brien, pp. 218-240. Center for American Archeology Press, Kampsville, Illinois.

Lurie, R. and R. Jeske

1990 Appendix 1: Chipped-stone Scheme and Documentation. In At the Edge of Prehistory: Huber Phase Archaeology in the Chicago Area, edited by J. A. Brown and P. J. O'Brien, pp. 284-294. Center for American Archeology

Marshall, J. Press, Kampsville, Illinois.

1969 The Glen Elder Focus: The Cultural Affiliations of Archeological Material from the Glen Elder Site, 14ML1.Department of Anthropology, University of Nebraska, Lincoln.

McLean, J.

1998 Lithic Raw Material Use at the DB Site. In Prehistoric Settlement of the Lower Missouri Uplands: The View from DB Ridge, Fort Leavenworth, Kansas, edited by B. Logan, pp. 167-197. Project Report Series, No. 98, University of Kansas Museum of Anthropology, Lawrence.

Morrow, $\mathrm{T}$.

1984 Iowa Projectile Points. Special Publication. Office of the State Archaeologist, The University of Iowa, Iowa City.

1994 A Key to the Identification of Chipped-Stone Raw Materials Found on Archaeological Sites in Iowa. Journal of the Iowa Archeological Society 41:108129.

Neuman, R. W.

1956 Field notes. Copies of original notes provided by author. On file with the Kansas State University Archaeology Lab, Manhattan, Kansas.

1963 Archeological Salvage Investigations in the Lovewell Reservoir Area, Kansas. River Basin Surveys Paper 32, Bulletin 185. Bureau of American Ethnology, Smithsonian Institution, Washington D.C.

Owada, I. and L. W. Ritterbush

1999 Changes in Late Prehistoric Arrowpoint Technology in North-Central Kansas. Paper presented at the 21st Annual Flint Hills Archaeological Conference, Lawrence.

Penman, J. T. and K. Hamilton

1990 Prehistoric Sites in La Crosse County, Wisconsin. Archaeological Report 17. Wisconsin Department of Transportation, Madison.

Ritterbush, L. W.

1998 Expanding Our Understanding of the White Rock Phase. Paper presented at the 56th Annual Plains Anthropological Conference, Bismarck, North Dakota.

2001 Temper in White Rock Site Ceramics. Current Archaeology in Kansas 2:714.

2002a Drawn by the Bison: Late Prehistoric Native Migration in the Central Plains. Great Plains Quarterly 22(4):259-270.

2002b Late Prehistoric Oneota in the Central Plains. Unpublished manuscript under review. 
2002c Western Oneota Contact Across the Plains. Paper presented at the 60th Annual Plains Anthropological Conference, Oklahoma City.

2003 Oneota Participation in Trans-Plains Exchange. Manuscript on file, Department of Sociology, Anthropology and Social Work, Kansas State University, Manhattan, Kansas.

Ritterbush, L. W. and B. Logan

1991 The Schultz Archaeological Project, Phase I: A Survey of Selected Prehistoric Sites in North-Central Kansas. Project Report Series No. 73. Museum of Anthropology, University of Kansas, Lawrence.

$\rightarrow 2000$ Late Prehistoric Oneota Population Movement into the Central Plains. Plains Anthropologist 45(173):257-272.

Rusco, M. K

1960 The White Rock Aspect. Notebook 4. The University of Nebraska Laboratory of Anthropology, Lincoln.

$\rightarrow$ Sollberger, J. B.

1971 A Technological Study of Beveled Knives. Plains Anthropologist 16(53):209218.

Stein, $M$.

2004 Sources of Smoky Hill Silicified Chalk in Northwest Kansas. Report prepared by the Archeology Office of the Kansas State Historical Society and submitted to the Midwest Archeological Center, National Park Service,

Straffin, D. Lincoln.

1971 The Kingston Oneota Site. Report 2. Office of the State Archaeologist, The University of Iowa, Iowa City.

Thies, R. M.

2002 Connie's Cache and the Hetzell Biface: Jasper in Northeast Kansas. Paper presented at the 24th Annual Flint Hills Archaeological Conference, Manhattan, Kansas.

2003 Jasper Bifaces Big and Small: Iva's Cache and Liggett's Cache. Paper presented at the $25^{\text {th }}$ Annual Flint Hills Archaeological Conference, Topeka, Kansas.

Wedel, W. R.

1959 An Introduction to Kansas Archeology. Bulletin 174, Smithsonian Institution, Bureau of American Ethnology, Washington D.C.

Wright, C. M.

1985 The Complex Aspects of the "Smokey [sic] Hill Jasper," Now Known as Niobrarite. Journal of the Kansas Anthropological Association 5(3):87-90. 